\title{
BINDING AND CATALYTIC REDUCTION OF NO BY TRANSITION METAL ALUMINOSILICATES
}

Technical Progress Report for the Period

June-August 1992

\author{
Kamil Klier \\ and \\ Richard G. Herman \\ with \\ Shaolie Hou \\ Zettlemoyer Center for Surface Studies \\ and Department of Chemistry \\ Lehigh University \\ Bethlehem, PA 18015
}

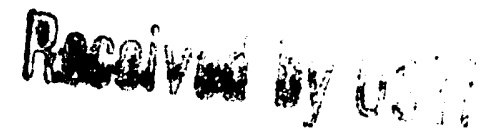

JAN $2 S 1033$

September 1992

PREPARED FOR THE UNITED STATES

DEPARTMENT OF ENERGY

Under Contract No. DE-FG22-89PC89784 


\title{
BINDING AND CATALYTIC REDUCTION OF NO BY TRANSITION ME'TAL ALUMINOSILICATES
}

\begin{abstract}
Disclaimer
This report was prepared as an account of work sponsored by the United States Government. Neither the United States nor the United States DOE, nor any of their employees, nor any of their contractors, subcontractors, or their employees, makes any warranty, express or implied, or assumes any legal liability or responsibility for the accuracy, completeness, or usefulness of any information, apparatus, product or process disclosed, or represents that its use would not infringe privately owned rights.
\end{abstract}




\section{BINDING AND CATALYTIC REDUCTION OF NO BY TRANSITION METAL ALUMINOSILICATES}

\section{OBJECTIVE AND SCOPE OF WORK}

The objective of this research is to provide the scientific understanding of processes that actively and selectively reduce NO in dilute exhaust streams, as well as in concentrated streams, to $\mathrm{N}_{2}$. Experimental studies of NO chemistry in transition metal-containing aluminosilicate catalysts are being carried out with the aim of determining the chemical rules for NO reduction on non-precious metals.

The catalyst supports chosen for this investigation are $\mathrm{A}$ and $\mathrm{Y}$ zeolites, mordenite, and monoliths based on cordierite. The supported transition metal cations that will be examined are principally the first row redox metals, e.g. $\mathrm{Cr}(\mathrm{II}), \mathrm{Mn}(\mathrm{II}), \mathrm{Fe}(\mathrm{II}), \mathrm{Co}(\mathrm{II}), \mathrm{Ni}(\mathrm{II})$, $\mathrm{Cu}(\mathrm{II})$, and $\mathrm{Cu}(\mathrm{I})$. The reactions of interest are the reductions of $\mathrm{NO}$ by $\mathrm{H}_{2}, \mathrm{CO}$, and $\mathrm{CH}_{4}$, as well as the disproportionation of NO.

In order to stabilize the transition metal cations in accessible sites and with desired oxidation states so that the resultant activity and selectivity to NO reduction are increased, rare earth cations that possess redox properties will be placed in the more shielded sites, e.g. Site I in Y zeolite, prior to or simultaneously with the exchange procedure with the transition metal cations. The rare earth redox couples that can be utilized include $\mathrm{Ce}(\mathrm{III}) / \mathrm{Ce}(\mathrm{IV}), \mathrm{Eu}(\mathrm{II}) / \mathrm{Eu}(\mathrm{III}), \mathrm{Sm}(\mathrm{II}) / \mathrm{Sm}$ (III), and $\mathrm{Pr}(\mathrm{III}) / \operatorname{Pr}(\mathrm{IV})$. The prepared catalysts will be tested in batch, pulsed, recycle, and continuous flow reactors with in-line gas chromatographic or mass spectrometric analyses, and they will be fully characterized before and after catalytic testing. 
To provide insight into the functioning of the redox cations and guidance in chosing the best transition metal/rare earth combination for the dissociative chemisorption of NO, theoretical calculations of the electronic structure of the transition metal cations in zeolitic sites will be carried out by ab initio methods, such as the scattered wave $X_{a}$ and Gaussian 86 or 90 packages. The aim of this part of the research is to find the best match between the metal-based antibonding orbitals and the antibonding orbitals of the NO molecule such that the $\mathrm{N}-\mathrm{O}$ bond is weakened and is readily broken. 


\section{BINDING AND CATALYTIC REDUCTION OF NO BY TRANSITION METAL ALUMINOSILICATES}

\section{SUMMARY OF TECHNICAL PROGRESS}

Extensive series of experiments were carried out with Co(II)A zeolites containing 2.6 and $3.9 \mathrm{Co}^{2+}$ ions per unit cell in which $\mathrm{NO}$ and $\mathrm{N}_{2} \mathrm{O}$ were separately adsorbed, and subsequent temperature programmed desorption (TPD) and optical spectroscopy analyses were carried out to study the desorption and decomposition behavior of these catalysts toward the adsorbates. The solid phase was monitored by optical diffuse reflectance (UVVis-NIR), while the gas phase was monitored by mass spectrometry. The experimental data are summarized here, and interpretation of these results is being carried out. 


\section{TECHNICAL PROGRESS}

\section{Complexation and Decomposition of $\mathrm{N}_{\mathbf{2}} \mathrm{O}$ on $\mathrm{CoA}$ zeolites}

\section{Room Temperature Isotherms of $\mathrm{N}_{2} \mathrm{O}$ on CoA Zeolites}

The dehydration of the $\mathrm{CoA}$ zeolite samples $\left(2.6 \mathrm{Co}^{2+} /\right.$ unit cell $)$ was carried out in the diffuse reflectance cell. Samples of about $2.5 \mathrm{~g} \mathrm{Co}^{2+} \mathrm{A}$ zeolites were outgassed for $6 \mathrm{hr}$ at $100^{\circ} \mathrm{C}$ and gradually heated up to $350^{\circ} \mathrm{C}$ at the rate of $50^{\circ} \mathrm{C}$ per $30 \mathrm{~min}$. Finally, the sample was kept at $350^{\circ} \mathrm{C}$ for another $6 \mathrm{hr}$ under a vacuum of about $10^{-5}$ torr pressure. The adsorption experiments were performed by gas expansion from the gas chamber (volume of $483 \mathrm{ml}$ ) into the cell (volume of $47 \mathrm{ml}$ ). The gas chamber was filled with gas at known pressure at room temperature. Following the pressure drop, measured by a differential manometer, the volumetric measurement was carried out with an optimal accuracy of approximately $2-5 \%$.

After the CoA zeolite was dehydrated, $\mathrm{N}_{2} \mathrm{O}$ adsorption experiments were carried out at room temperature. The amount of $\mathrm{N}_{2} \mathrm{O}$ adsorption depends on the pressure of $\mathrm{N}_{2} \mathrm{O}$ (Figure 1). For the sample with $2.6 \mathrm{Co}^{2+}$ per unit cell, there were up to $7 \mathrm{~N}_{2} \mathrm{O}$ molecules adsorbed by a unit cell. This corresponds to more than $2 \mathrm{~N}_{2} \mathrm{O}$ per Co cation. The adsorption rate became much slower after the CoA zeolite had adsorbed $\mathrm{N}_{2} \mathrm{O}$ corresponding to about $2 \mathrm{~N}_{2} \mathrm{O}$ per $\mathrm{Co}^{2+}$ ion. There was no detectable stable state corresponding to the adsorption of only one $\mathrm{N}_{2} \mathrm{O}$ per $\mathrm{Co}^{2+}$ cation. Upon evacuation at room temperature, $\mathrm{N}_{2} \mathrm{O}$ could be fully desorbed without decomposition. 


\section{2. $\underline{N}_{2} \mathrm{O}$ Decomposition on CoA Zeolite}

After exposure of the CoA zeolite to 750 torr of $\mathrm{N}_{2} \mathrm{O}$, followed by brief evacuation of the gas phase, the temperature of the sample was progressively increased to $350^{\circ} \mathrm{C}$. As the programmed temperature reached $150^{\circ} \mathrm{C}$, adsorbed $\mathrm{N}_{2} \mathrm{O}$ began to decompose, which was manifested by the release of $\mathrm{N}_{2}$. Oxygen is believed to be chemisorbed on the zeolite at the lower temperatures utilized, for when the temperature was increased to $300^{\circ} \mathrm{C}, \mathrm{O}_{2}$ was also released (Figure 2). The initial reaction can be written as follows:

$$
\mathrm{N}_{2} \mathrm{O}+\mathrm{CoA} \stackrel{150^{\circ} \mathrm{C}}{\rightarrow} \mathrm{CoA}-\mathrm{O}_{\text {chem }}+\mathrm{N}_{2} .
$$

CoA- $\mathrm{O}_{\text {chem }}$ sites with chemisorbed oxygen are rather stable up to $300^{\circ} \mathrm{C}$, and they more readily decompose above this temperature with liberation of $\mathrm{O}_{2}$, i.e

$$
\mathrm{CoA}-\mathrm{O}_{\text {chem }} \stackrel{300^{\circ} \mathrm{C}}{\rightarrow} \mathrm{CoA}+0.5 \mathrm{O}_{2}
$$

Since the reaction of gas phase $\mathrm{O}_{2}$ with $\mathrm{CoA}$ at $150-350^{\circ} \mathrm{C}$ does not result in its chemisorption, CoA- $\mathrm{O}_{\text {chem }}$ sites are apparently formed as a result of chemisorption of $\mathrm{O}$ atoms and not the $\mathrm{O}_{2}$ molecule.

\section{UV-VIS-NIR Spectra of $\mathrm{N}_{2} \mathrm{O}$ on CoA Zeolites}

The most significant spectral change after $\mathrm{N}_{2} \mathrm{O}$ adsorption at ambient temperature was that the characteristic peaks for bare site $\mathrm{Co}^{2+}$ at 24,000 and $25,000 \mathrm{~cm}^{-1}$ (Figure 3) were completely absent when the Co cation adsorbed more than one $\mathrm{N}_{2} \mathrm{O}$ molecule (Figure 4-5). The addition of the 14,500 and $21,000 \mathrm{~cm}^{-1}$ peaks (Figure 6) contributed to the broadening of the original 16,000 and $18,500 \mathrm{~cm}^{-1}$ peaks. Increasing the pressure of $\mathrm{N}_{2} \mathrm{O}$ after reaching the level of one $\mathrm{N}_{2} \mathrm{O}$ molecule per Co cation level did not change the 
spectrum except for only increasing the intensity of those peaks. After evacuation at room temperature, the spectrum corresponded to that of the original bare site $\mathrm{Co}^{2+}($ Figure 3 ) and was fully recovered.

When $\mathrm{CoA}$ was heated in the present of $\mathrm{N}_{2} \mathrm{O}$ (750 torr), the background of the optical spectra was increased (Figures 7 and 8). The peaks at 14,500 and $21,000 \mathrm{~cm}^{-1}$ gradually disappeared, and the $24,500-25,000 \mathrm{~cm}^{-1}$ band appeared as shown in Figure 9 (during this temperature region, $\mathrm{N}_{2}$ was released, see Figure 10). When the temperature reached above $300^{\circ} \mathrm{C}$, the 24,000 and $25,000 \mathrm{~cm}^{-1}$ peaks were partially recovered but did not fully recover at $350^{\circ} \mathrm{C}$, as shown in Figure 11 (during this temperature region, $\mathrm{O}_{2}$ was also released as shown in Figure 10). Desorption at lower temperature did not change the spectra, but the profound evacuation at $350^{\circ} \mathrm{C}$ almost completely regenerated bare site $\mathrm{Co}^{2+}$ as indicated by the spectrum shown in Figure 12. Reduction of this sample by $\mathrm{H}_{2}$ at $350^{\circ} \mathrm{C}$ fully regenerated the sample, and the products observed were water and nitrogen.

During the heating in the present of $\mathrm{N}_{2} \mathrm{O}$, there was a slight color change noted at $250^{\circ} \mathrm{C}$. The sample became a greenish color, and the color became quite intense at $300^{\circ} \mathrm{C}$. It changed back to dark blue at $350^{\circ} \mathrm{C}$.

\section{Complexation and Decomposition of NO on CoA zeolites}

\section{Room Temperature Isotherms of NO on CoA Zeolites}

Prior to these studies, the zeolite samples were dehydrated as described in the previous section of this report. The amount of NO adsorption on CoA zeolites at ambient temperature depends on the pressure of NO (Figure 13). For the sample containing 3.9 $\mathrm{Co}^{2+}$ ions per unit cell that was used for these experiments, there were up to 11 NO 
molecules adsorbed per unit cell at 750 torr of NO. This corresponds to $2.8 \mathrm{NO}$ per $\mathrm{Co}^{2+}$ cation. There was no stable state observed that would correspond to only one $\mathrm{NO}$ per $\mathrm{Co}^{2+}$ cation. Upon evacuation at room temperature, $\mathrm{NO}$ was partially desorbed with some $\mathrm{N}_{2} \mathrm{O}$ formation since the latter component was detected in the desorbed gases. This indicated that the adsorption of $\mathrm{NO}$ was stronger than that of $\mathrm{N}_{2} \mathrm{O}$ and that the $\mathrm{NO}$ was much more activated than $\mathrm{N}_{2} \mathrm{O}$.

\section{NO Decomposition on COA Zeolites}

After exposure of the CoA zeolite $(10 \mathrm{mg})$ to 50 torr $\mathrm{NO}$, followed by brief evacuation at room temperature to remove the gas phase NO, temperature programmed studies were carried out. As the sample temperature was progressively raised from room temperature up to $350^{\circ} \mathrm{C}$, NO began to decompose, which was manifested by the release of $\mathrm{N}_{2}$ and $\mathrm{N}_{2} \mathrm{O}$ (Figure 14). The quantity of $\mathrm{N}_{2} \mathrm{O}$ desorbed reached a maximum around $200^{\circ} \mathrm{C}$, and the decrease at higher temperatures may be caused by subsequent decomposition of the $\mathrm{N}_{2} \mathrm{O}$ over the CoA zeolite. However, there was little oxygen released in this temperature region. The decomposition may be achieved via the surface complexes formed. After evacuation of the sample at $350^{\circ} \mathrm{C}$, a $\mathrm{H}_{2}$ reduction treatment was employed. This reduction treatment at $350^{\circ} \mathrm{C}$ (Figure 15) gave $\mathrm{H}_{2} \mathrm{O}, \mathrm{N}_{2}$ and $\mathrm{NO}$ as major products, which indicated that the surface complexes must involve oxygen and a higher valence state nitrogen. When a $\mathrm{H}_{2}$ and $\mathrm{NO}$ mixture was heated over the same zeolites at $350^{\circ} \mathrm{C}$, the only producis observed were $\mathrm{N}_{2}$ and $\mathrm{H}_{2} \mathrm{O}$ (Figure 16).

\section{UV-VIS-NIR Spectra of NO on CoA Zeolites}

The most significant spectral change after NO adsorption was the disappearance of the characteristic peaks for bare site $\mathrm{Co}^{2+}$ at 24,500 and $25,000 \mathrm{~cm}^{-1}$ when the Co cation 
adsorbed more than one NO molecule (Figure 17). At the same time, the absorption edge at $40,000 \mathrm{~cm}^{-1}$ moved towards lower wavenumbers, e.g. $36,000 \mathrm{~cm}^{-1}$, which indicated that charge transfer occurred. The intensity of the $16,000 \mathrm{~cm}^{-1}$ peak decreased with increasing NO pressure and split into two peaks. The $18,500 \mathrm{~cm}^{-1}$ peak was broadened by addition of the new peak at $20,500 \mathrm{~cm}^{-1}$. Evacuation at room temperature could not regenerate the original spectrum (Figure 18); however, the $16,000 \mathrm{~cm}^{-1}$ peak increased in intensity while the 20,500 peak decreased to form a 1:1 intensity ratio. The thermal desorption experiment extended up to $350^{\circ} \mathrm{C}$ partially regenerated the spectrum, which gave the original relative peak intensities at 16,000 and $18,500 \mathrm{~cm}^{-1}$ and reappearance of the $24,500-25,000 \mathrm{~cm}^{-1}$ band. However, the intensity of the latter peaks was much lower than the original intensity (the spectra intensity of the original sample to the NO treatment sample was about 4:1, as shown in the Figure 19). After $4 r_{2}$ reduction at $350^{\circ} \mathrm{C}$, the spectrum was fully regenerated.

When CoA zeolite was heated in the presence of NO (750 torr), the spectra showed similar features to those of the thermal desorption spectra. However, there was no recovery in the $24,500-25,000 \mathrm{~cm}^{-1}$ region. There was a new peak at $31,000 \mathrm{~cm}^{-1}$ when the treatment temperature was above $300^{\circ} \mathrm{C}$ (Figure 20). Evacuation at $350^{\circ} \mathrm{C}$ did not eliminate this peak, but the loss of this new peak was achieved by $\mathrm{H}_{2}$ reduction at the same temperature. The corresponding gas components after exposure of NO on CoA and after hydrogen reduction at various temperatures are shown in Figures 21 and 22, respectively. It is probably reasonable that no oxygen was detected, for oxygen will react with $\mathrm{NO}$ to form $\mathrm{NO}_{2}$ immediately at these reaction conditions. However, in the case of $\mathrm{N}_{2} \mathrm{O}$, the oxygen did not react with $\mathrm{N}_{2} \mathrm{O}$ and could recombine to form $\mathrm{O}_{2} . \mathrm{N}_{2} \mathrm{O}$ was not necessarily an intermediate in the NO decomposition. 


\section{Adsorption of $\mathrm{NO}_{2}$ on CoA Zeolites}

The adsorption of $\mathrm{NO}_{2}$ on CoA was studied by UV-VIS-NIR spectroscopy. The $\mathrm{NO}_{2}$ tested sample exhibited strong absorption spectral band centered at $\approx 32,000 \mathrm{~cm}^{-1}$ wavenumbers (Figure 23). Thermal desorption at $350^{\circ} \mathrm{C}$ did not generate the $24,500-25,000$ $\mathrm{cm}^{-1}$ peaks (Figure 24). This indicated that the adsorption of $\mathrm{NO}_{2}$ was stronger than that of $\mathrm{NO}$ and $\mathrm{N}_{2} \mathrm{O}$. Hydrogen reduction treatment at $350^{\circ} \mathrm{C}$ gave the same reduction products, $\mathrm{H}_{2} \mathrm{O}, \mathrm{N}_{2}$ and NO, as in the case of the NO treatment sample (Figure 22). Regeneration of the $24,500-25,000 \mathrm{~cm}^{-1}$ spectra feature could also be achieved by $\mathrm{H}_{2}$ reduction at the same temperature. However, complete regeneration required several cycles of hydrogen exposure and evacuation of the reduction products. These experiments indicate that $\mathrm{NO}_{2}$ may be a surface complex formed during the $\mathrm{NO}$ decomposition. The amount of $\mathrm{NO}_{2}$ formed was small and was strongly held by the surface. Thus, $\mathrm{NO}_{2}$ was not easily detected in the gas phase but was easily reduced by $\mathrm{H}_{2}$ in the case of NO decomposition. 
FIGURE 1

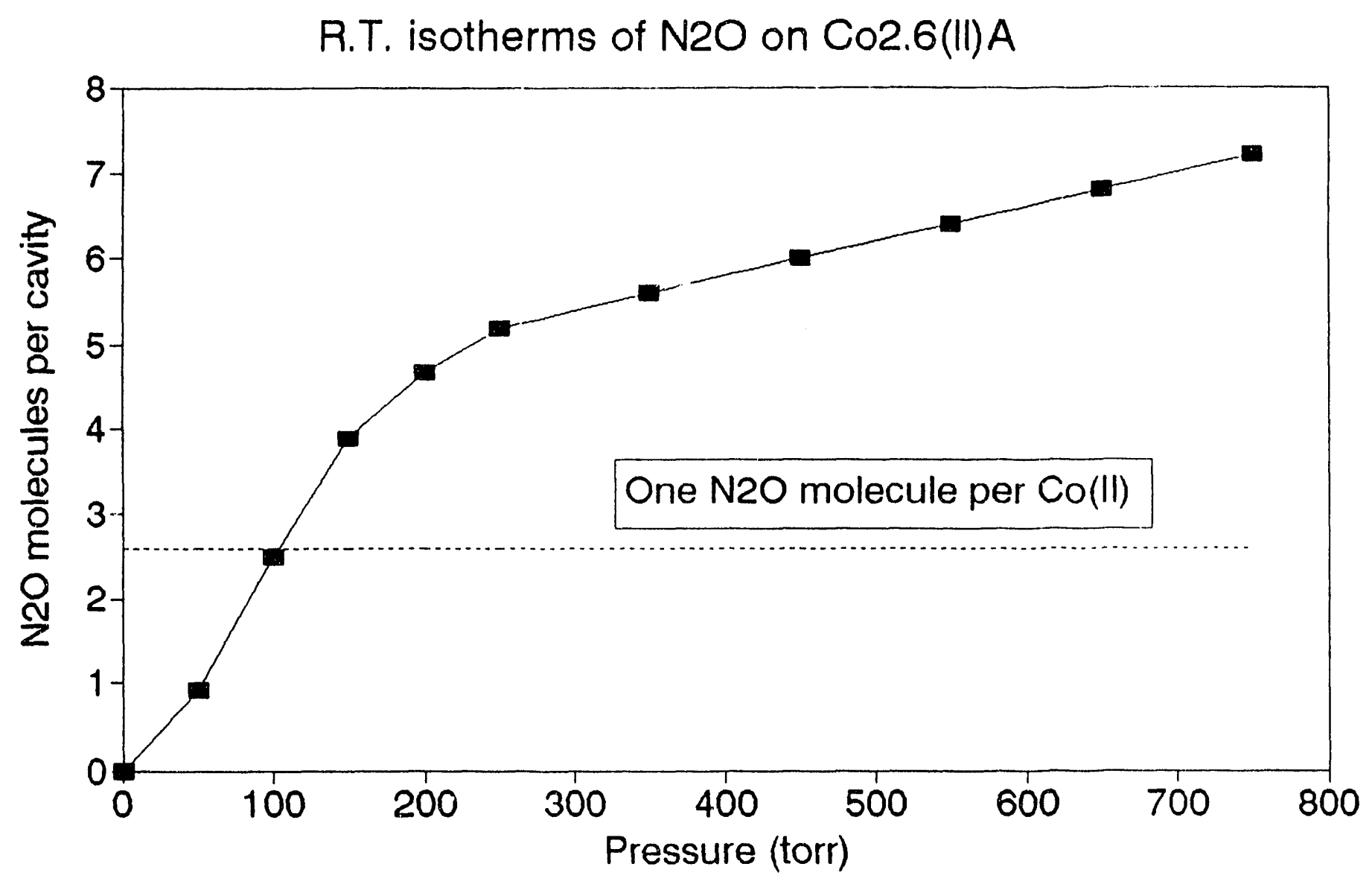

$-\mathrm{N} 2 \mathrm{O}$ 
FIGURE 2

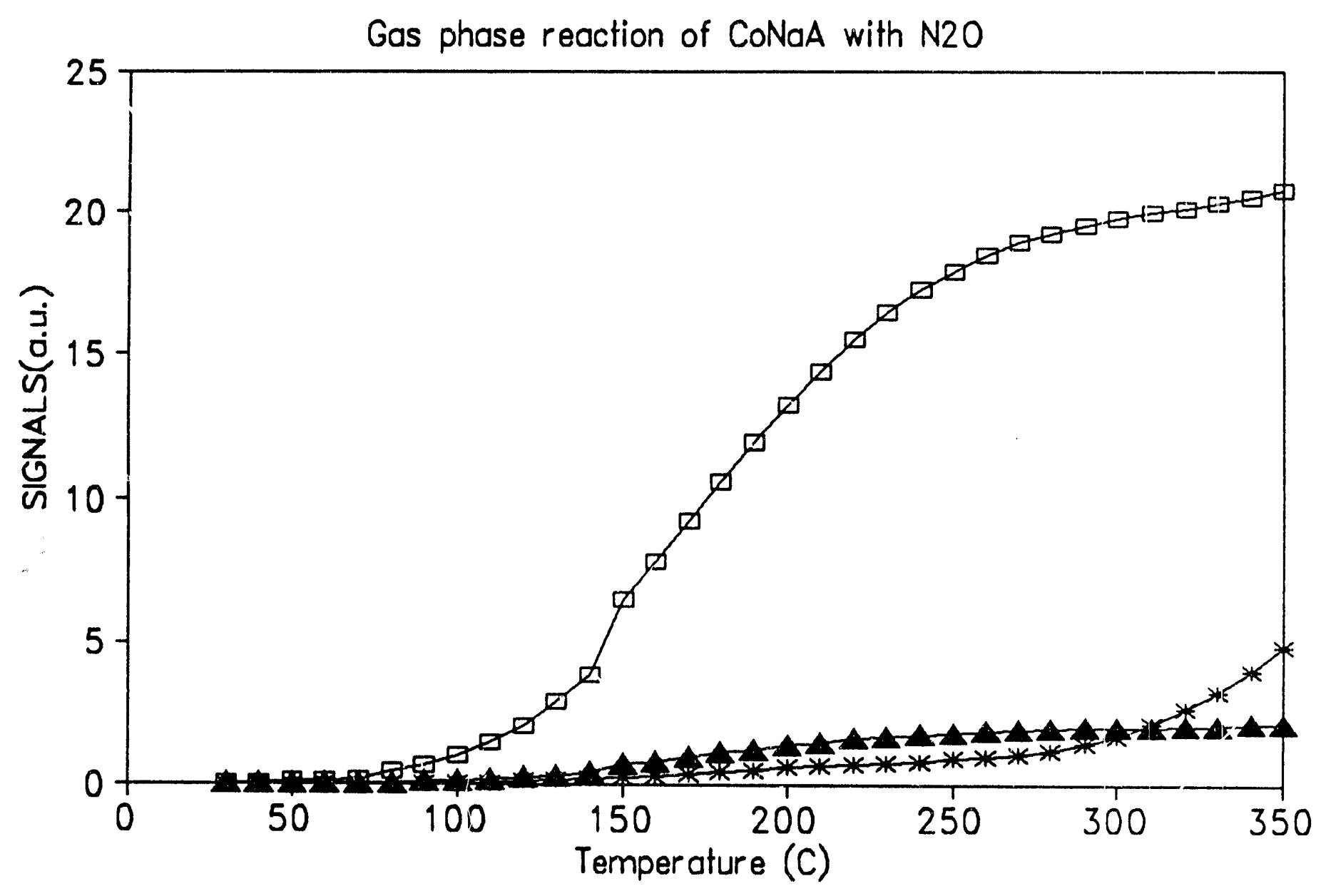

$$
\because \mathrm{N} 2 \mathrm{O} \rightarrow \mathrm{N} 2(\mathrm{x} 5) \rightarrow \mathrm{0} 2(\mathrm{x} 5)
$$




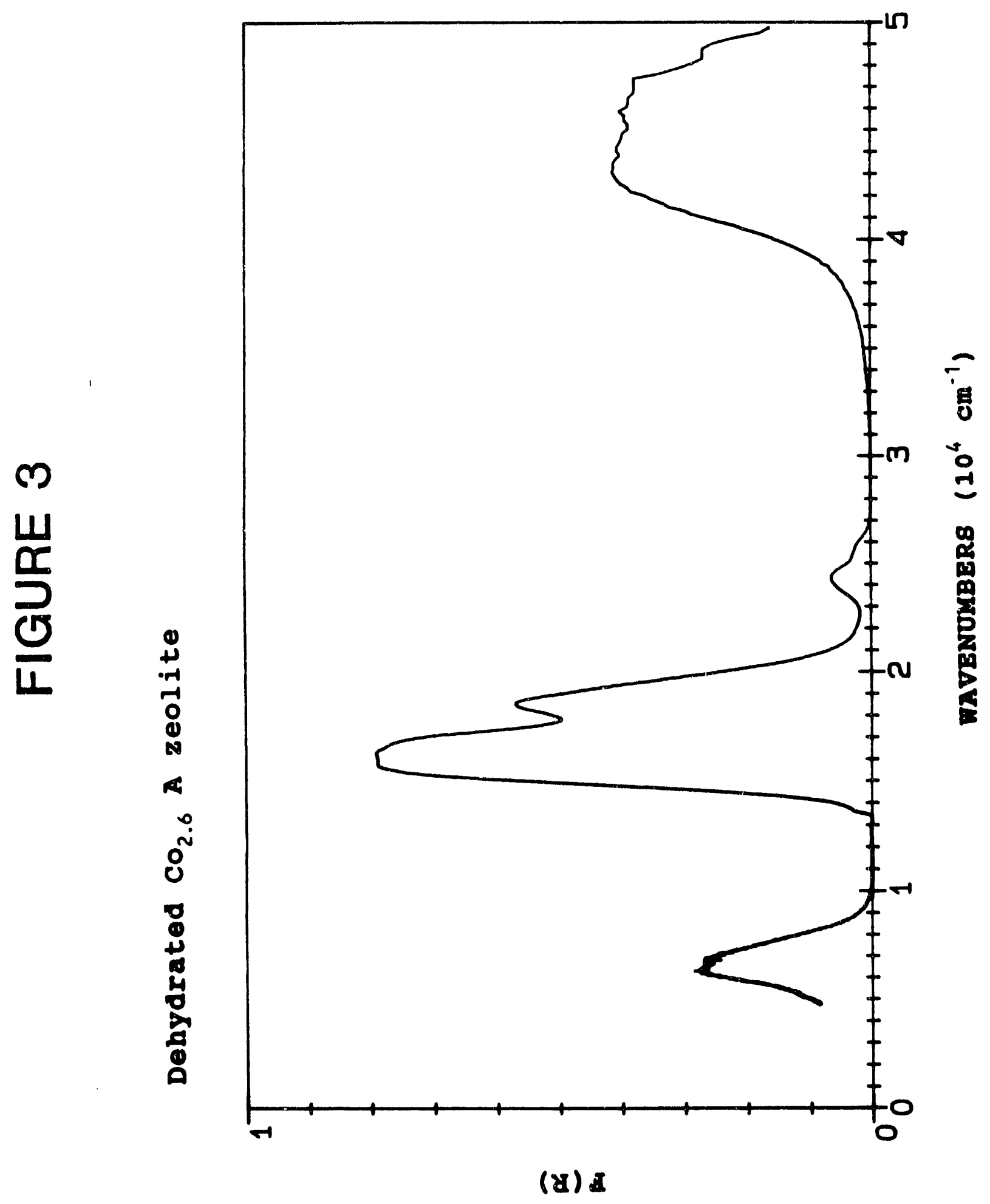




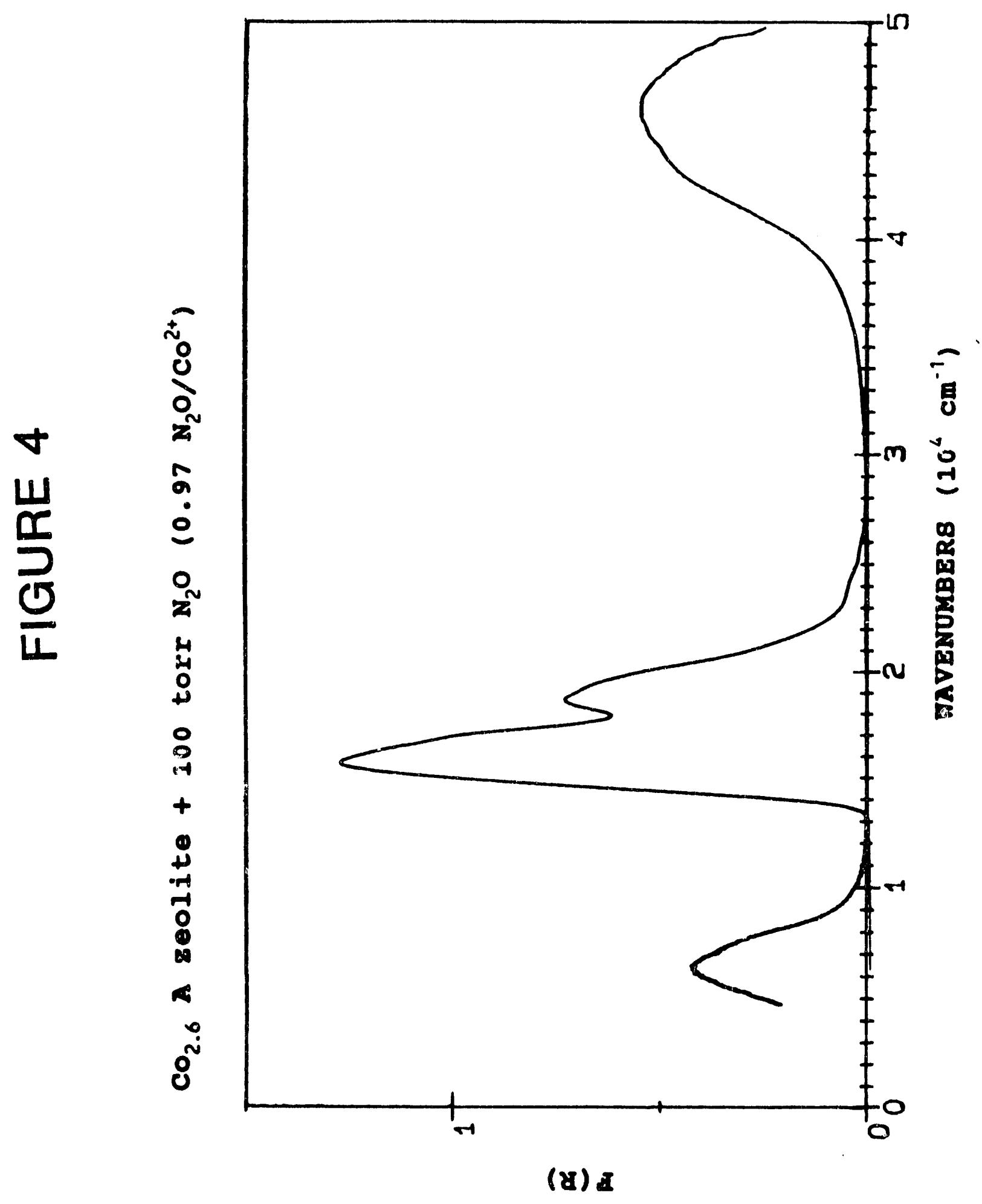




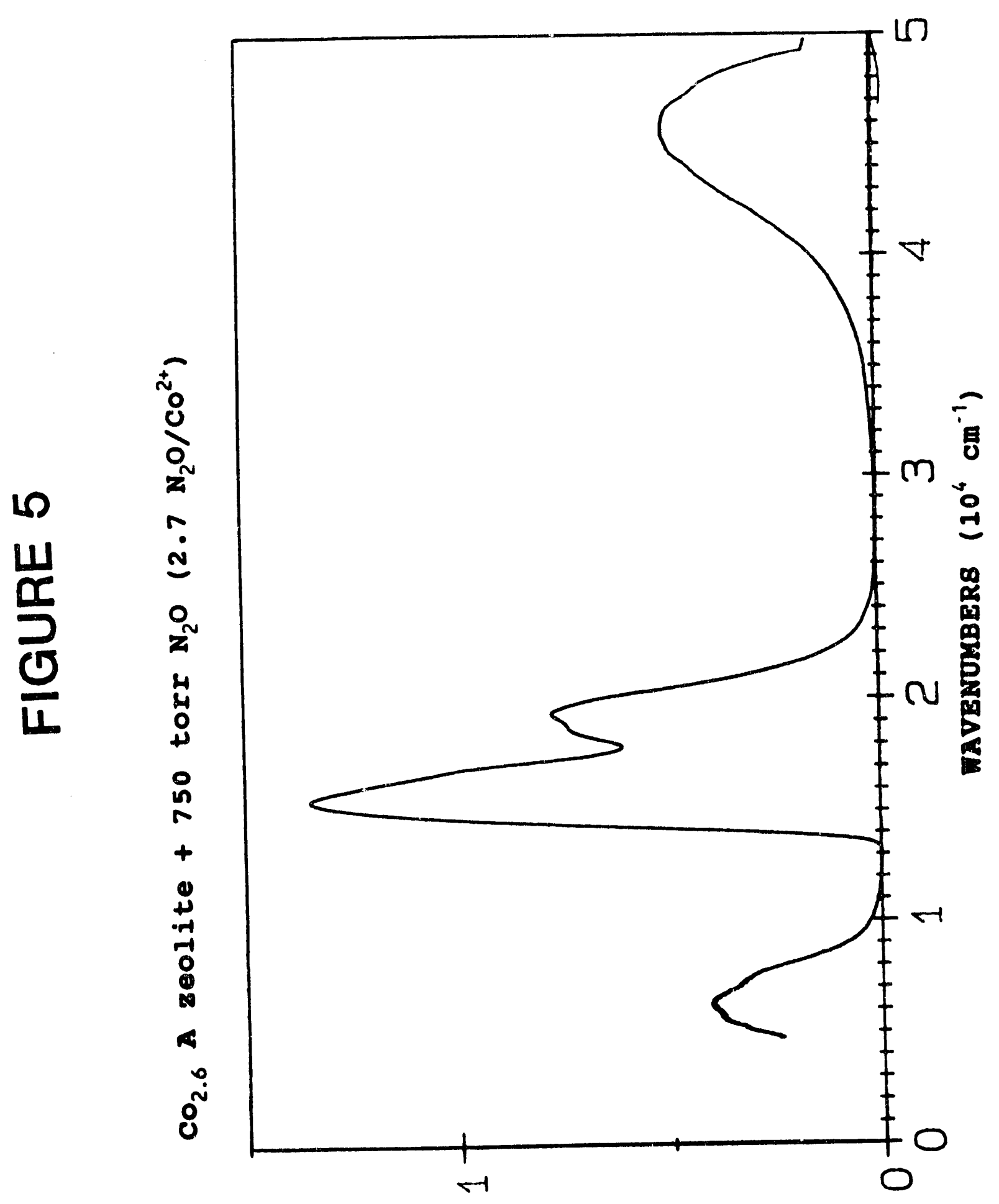

(8) $\pi$ 


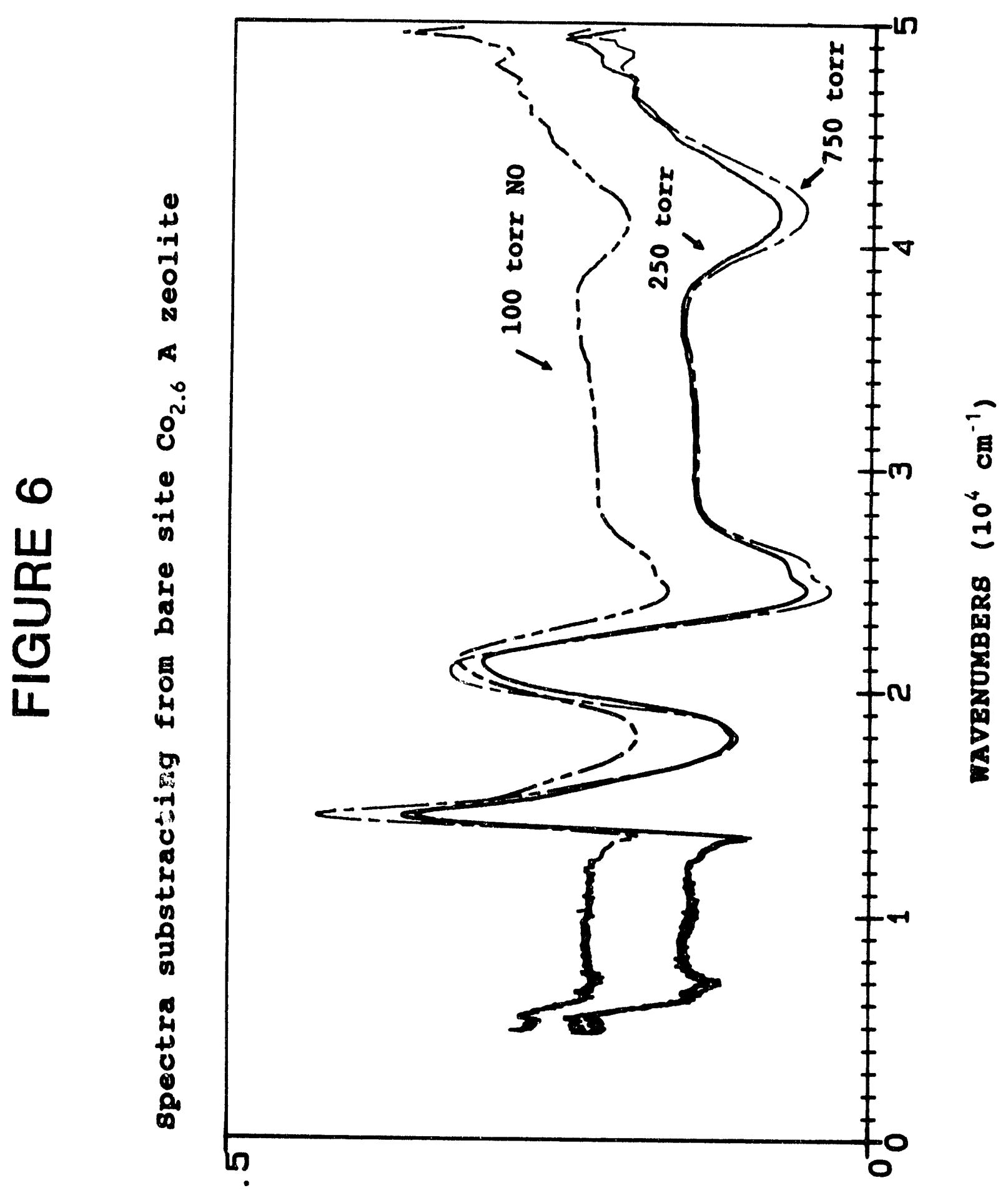

(घ) $x$ 


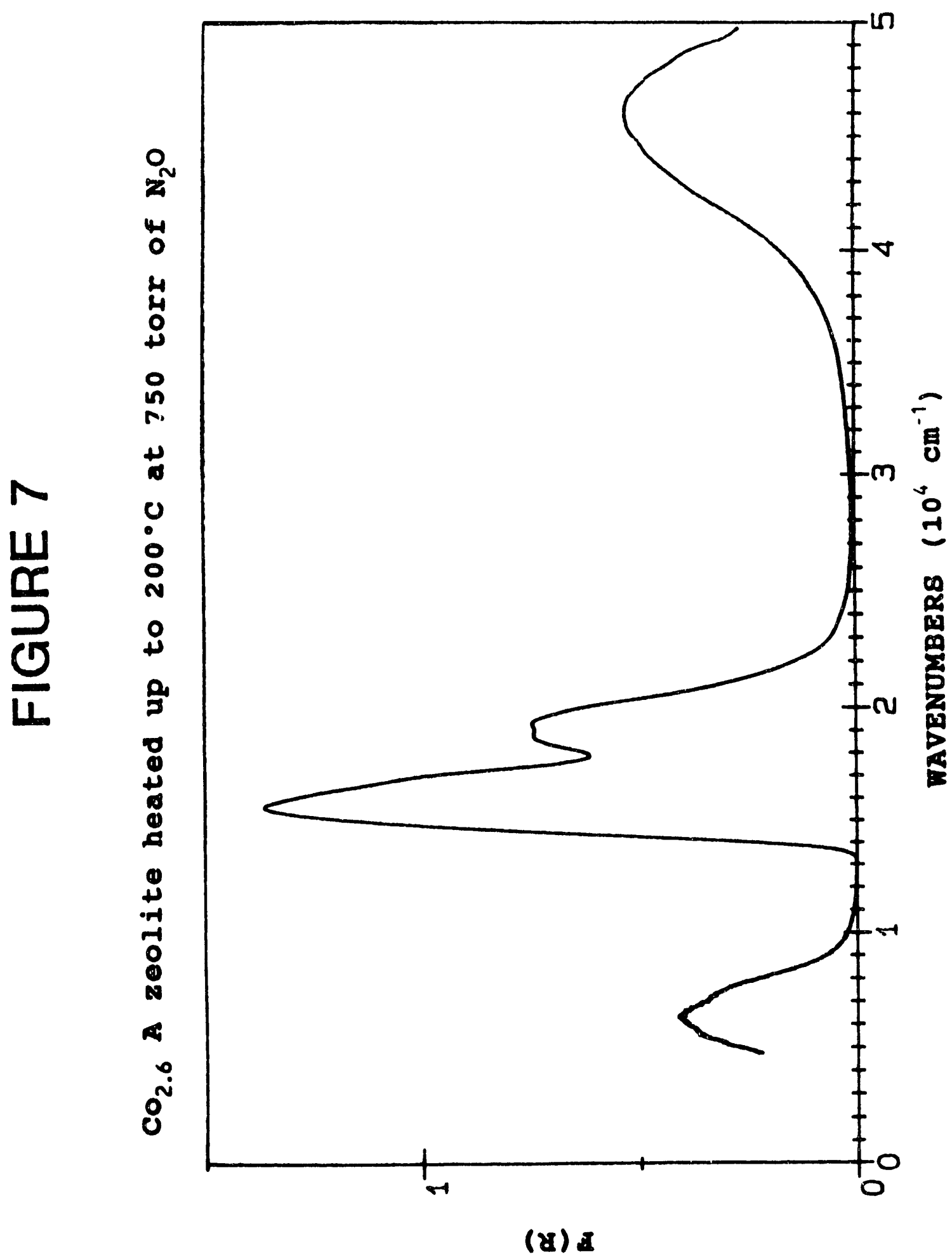




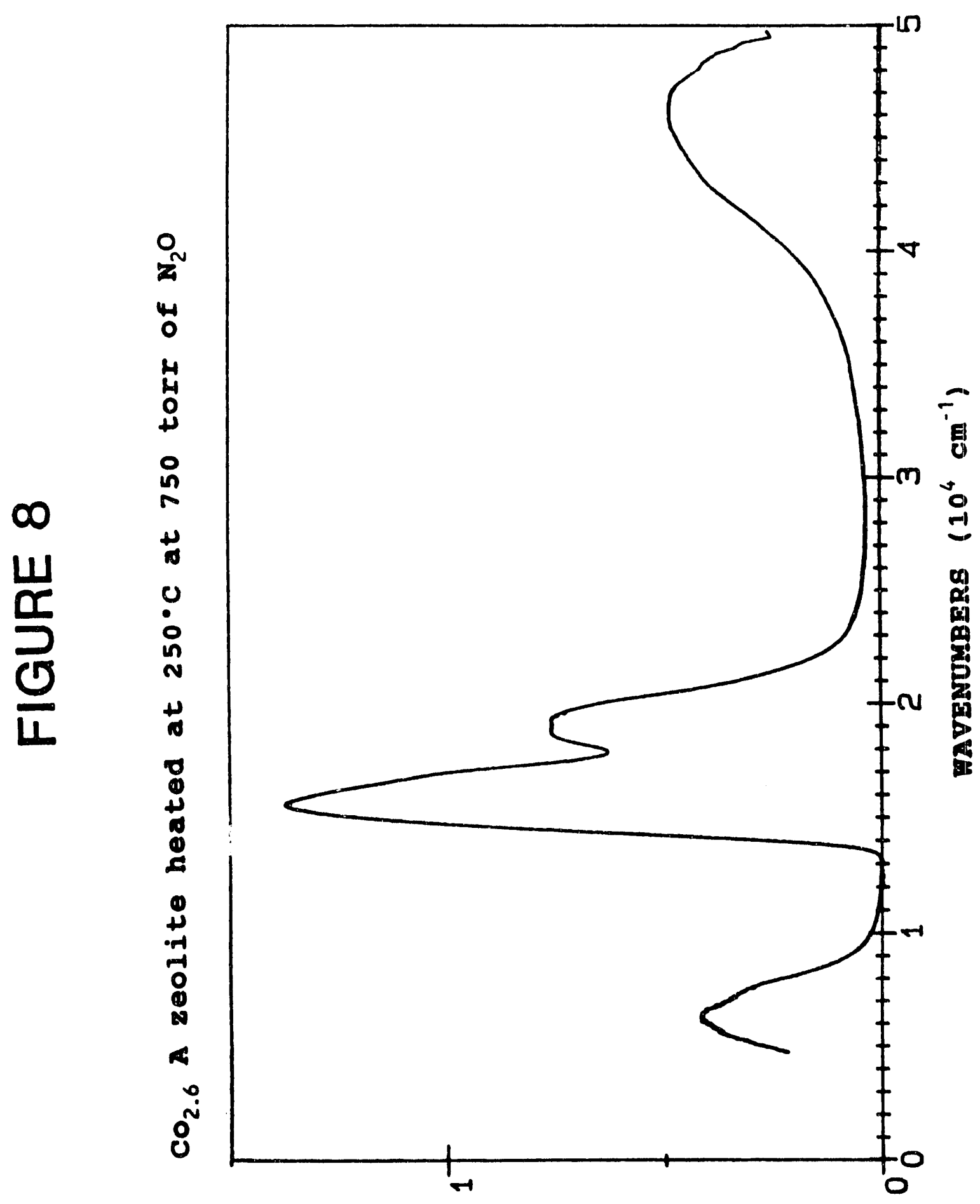

(8) 3 


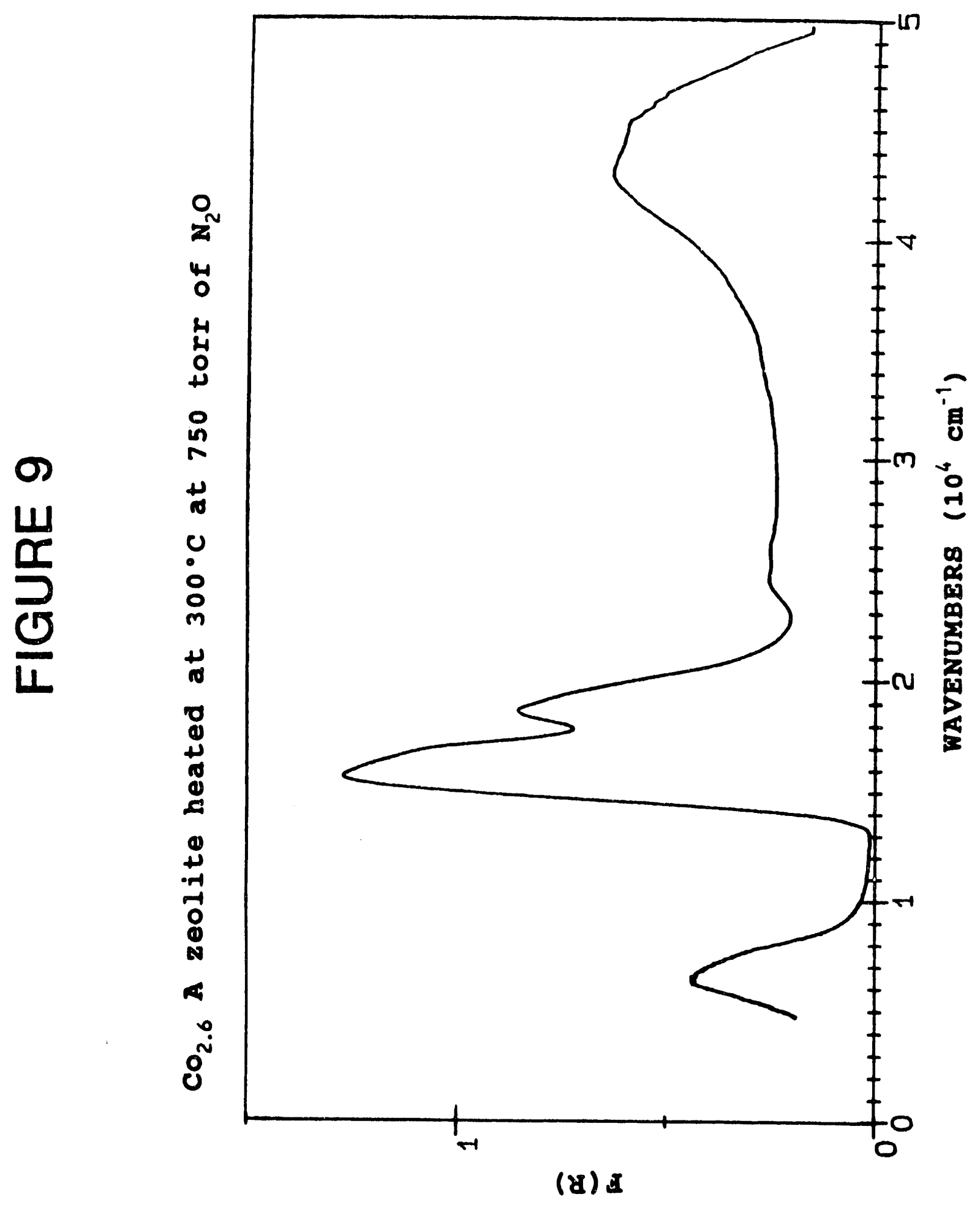




\section{FIGURE 10}

Gases Component of N2O(750 torr) on CoA at various temperatures.

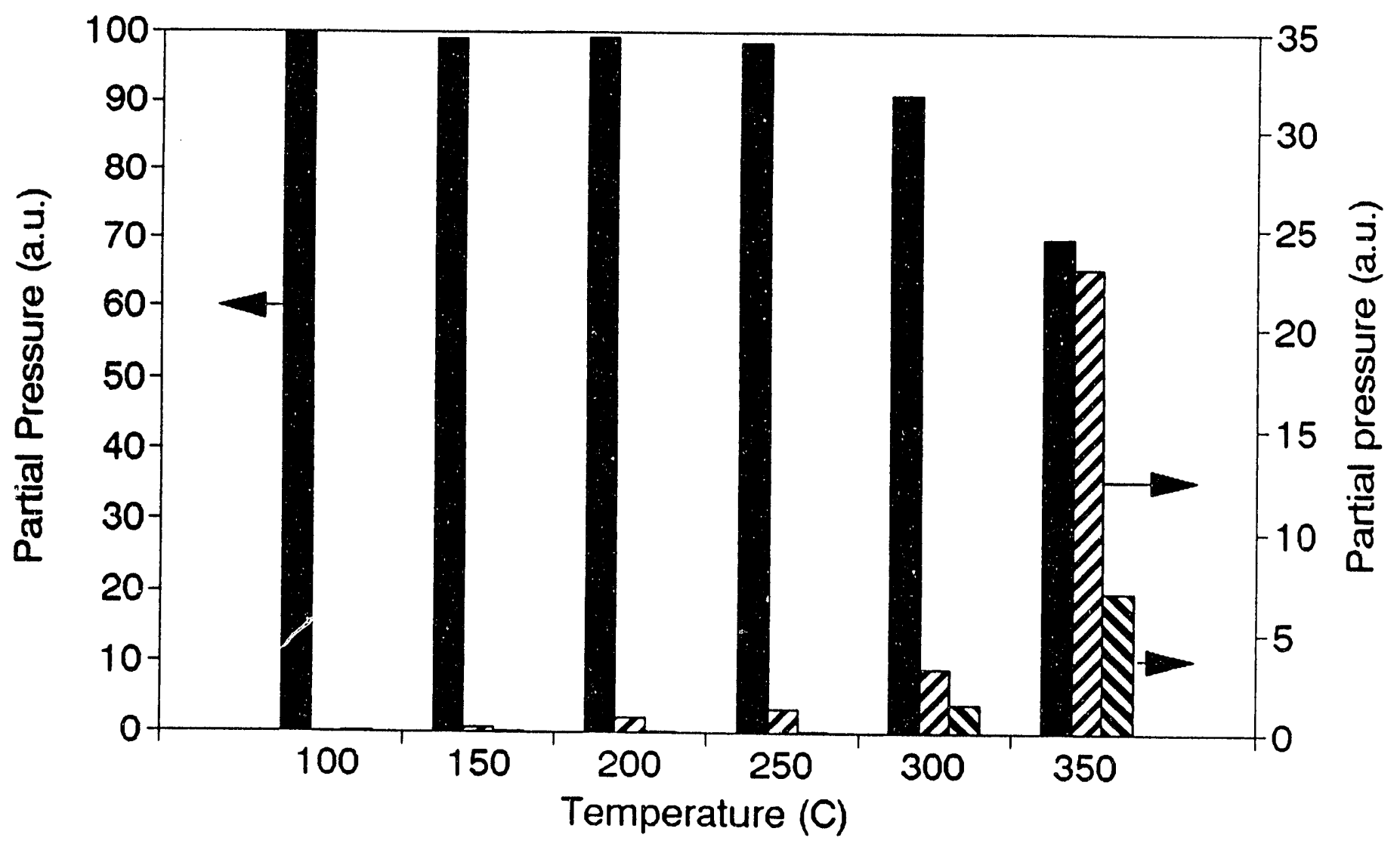

E2O שIA N2 AN O2 


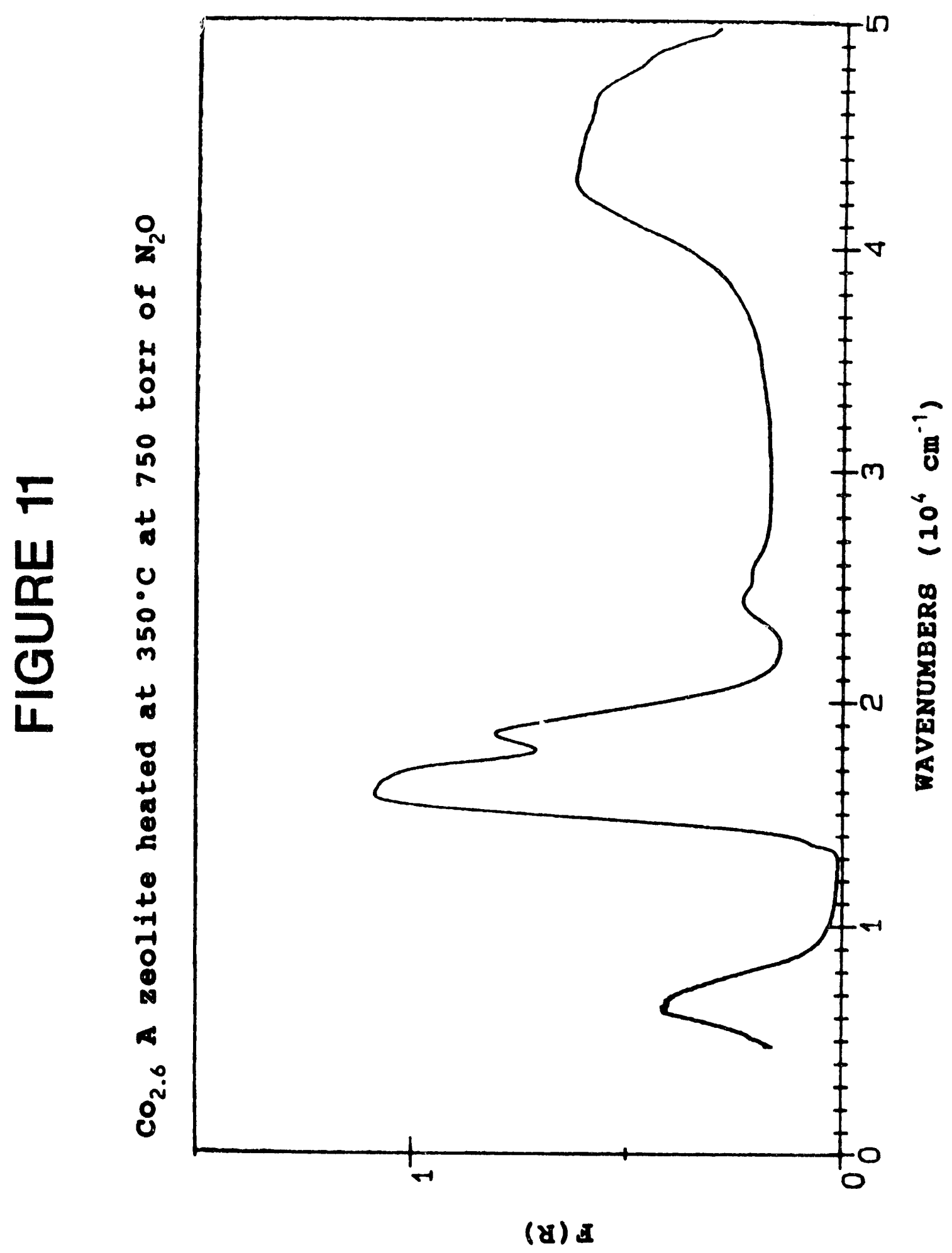




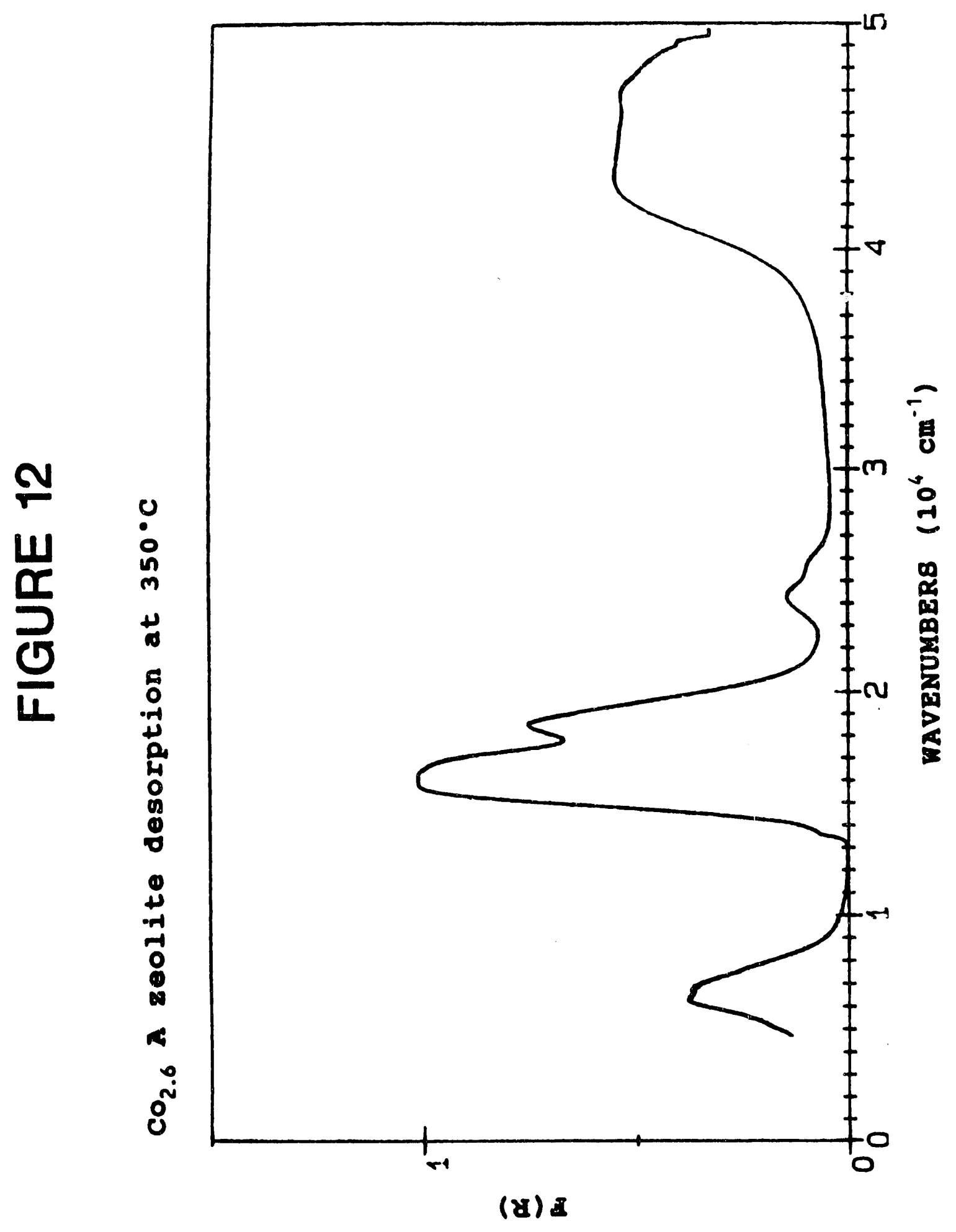


FIGURE 13

R.T. isotherms of NO on Co3.9A zeolite

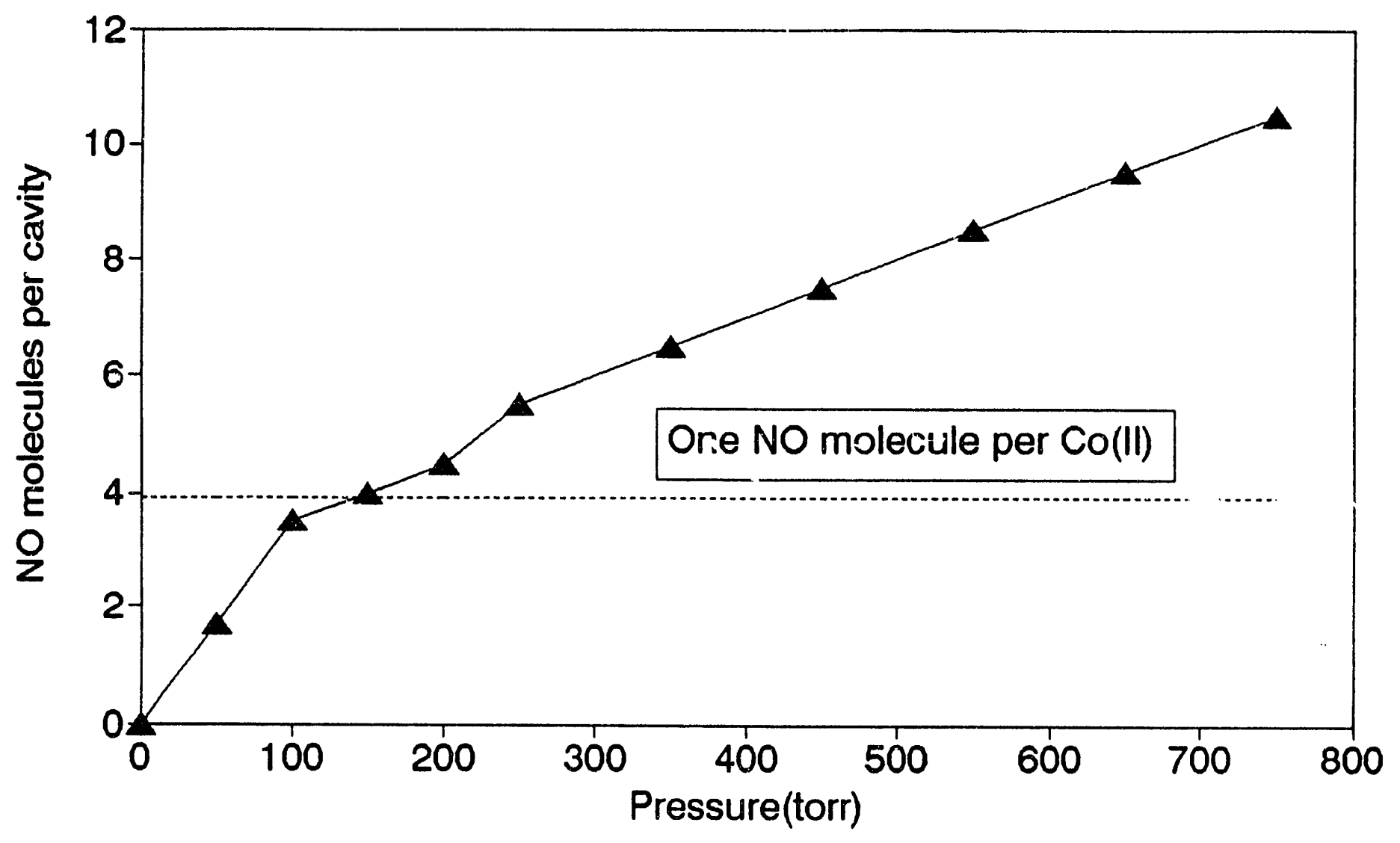

$\leftarrow$ NO 
FIGURE 14

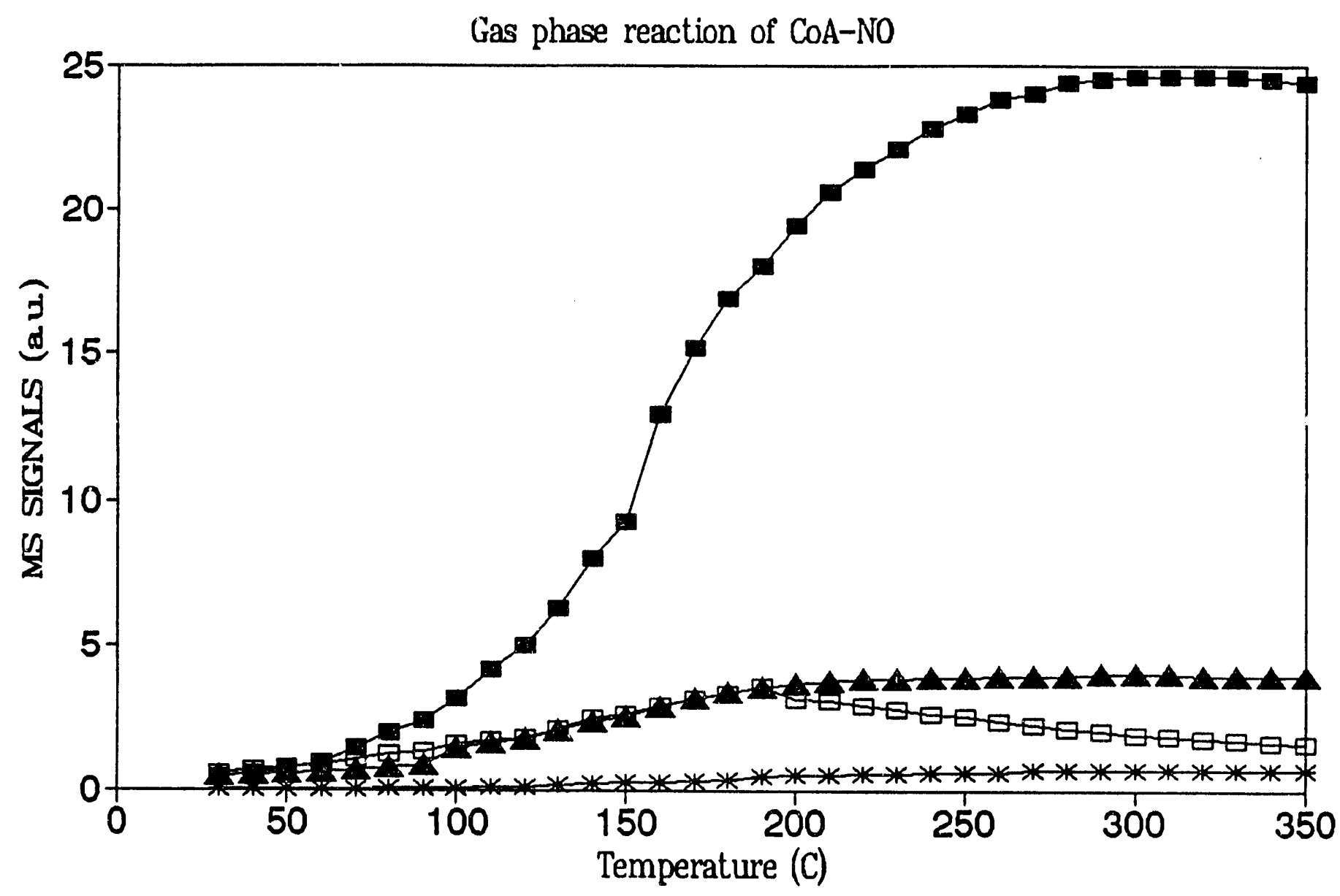

$\rightarrow-\mathrm{NO} \rightarrow \mathrm{N} 2 \mathrm{O}(\mathrm{x} 5) \rightarrow \mathrm{N} 2(\mathrm{x} 10) \rightarrow \mathrm{O} 2(\mathrm{x} 10)$ 


\section{FIGURE 15}

Gases components of $\mathrm{H} 2$ reduction of $\mathrm{CoA}$ at $350 \mathrm{C}$ after thermal evacuation.

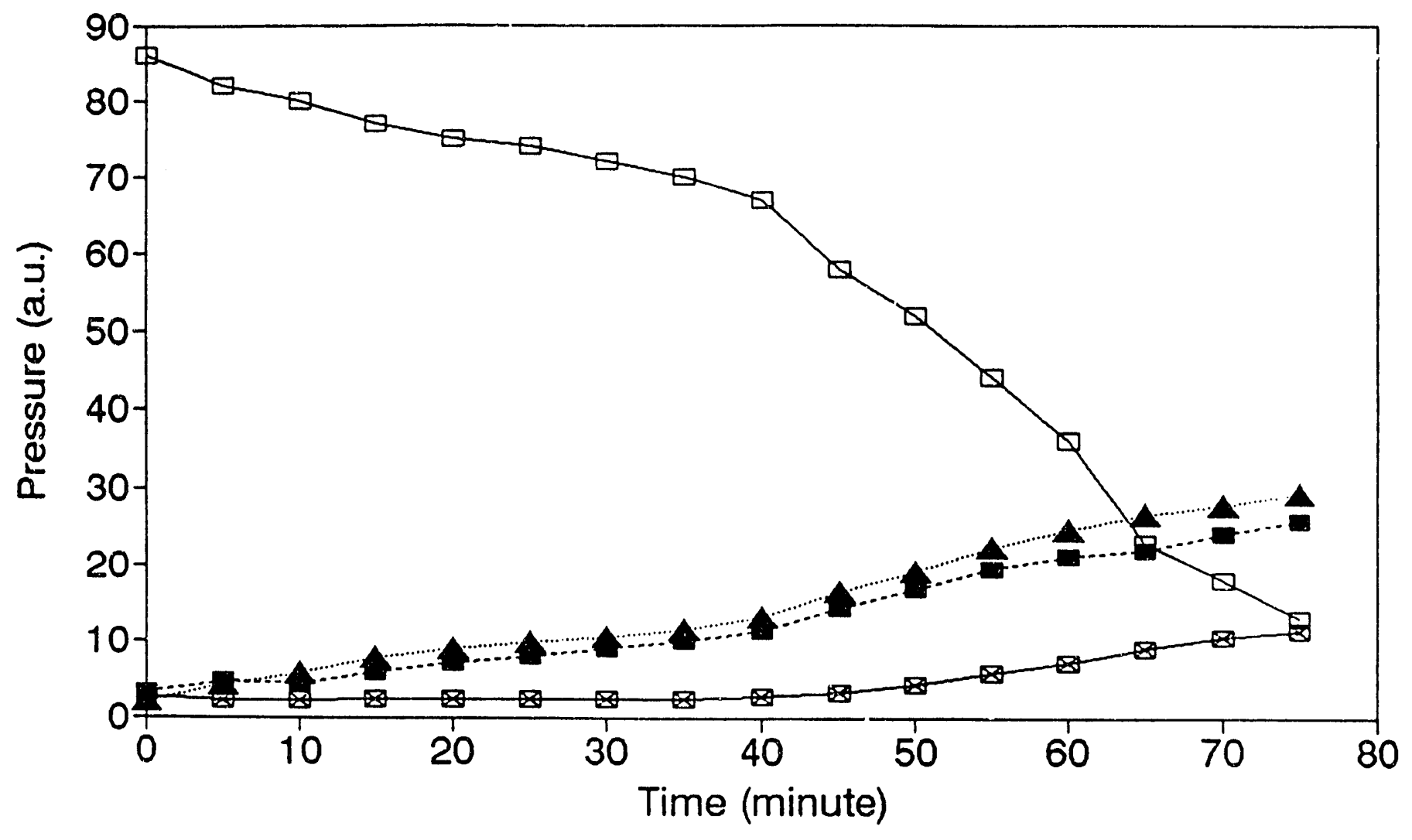

$\cdots \cdots \mathrm{N} 2 \quad \cdots \cdots \mathrm{NO} \rightarrow \mathrm{H} 2 \mathrm{O}-\square-\mathrm{H} 2$ 


\section{FIGURE 16}

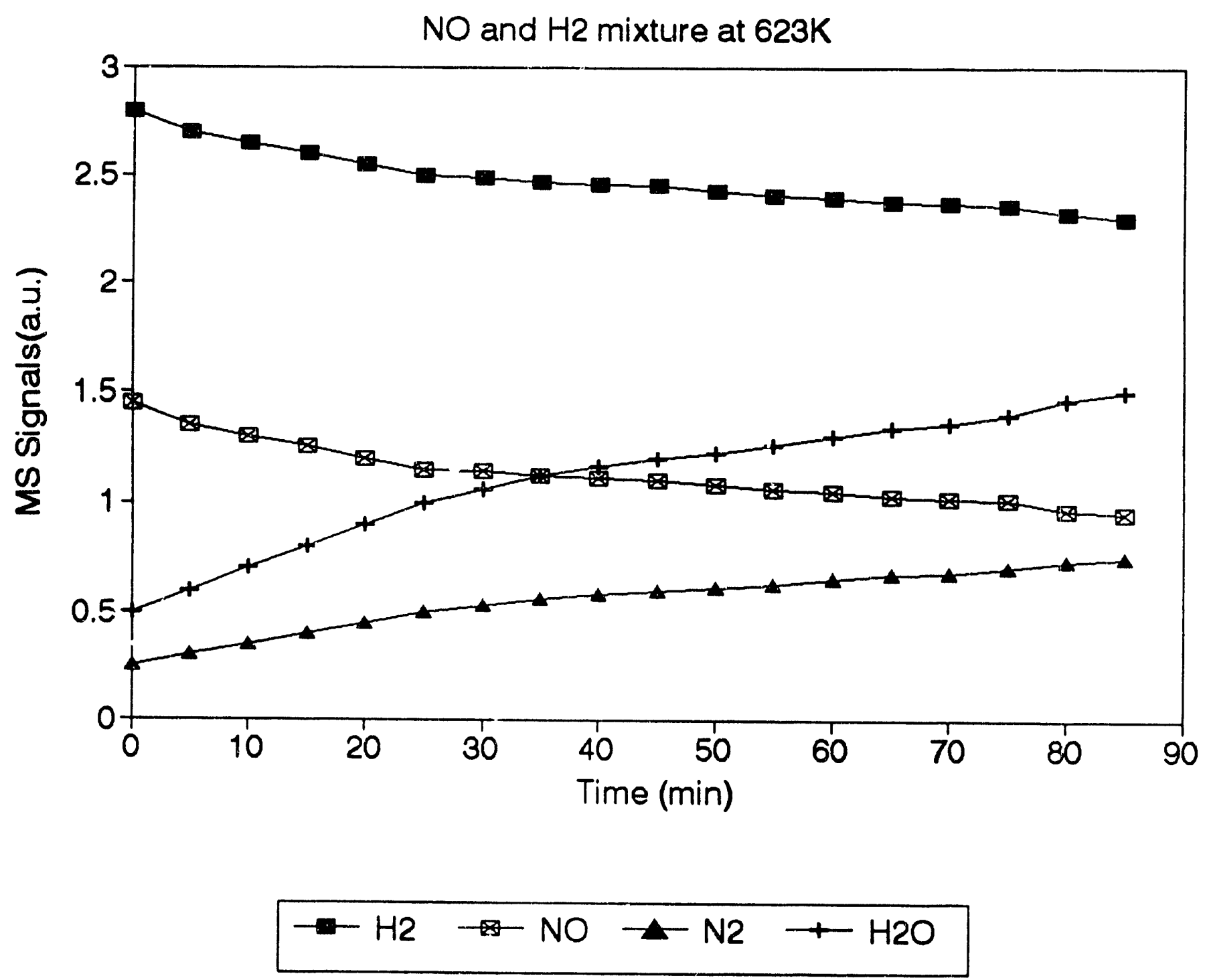




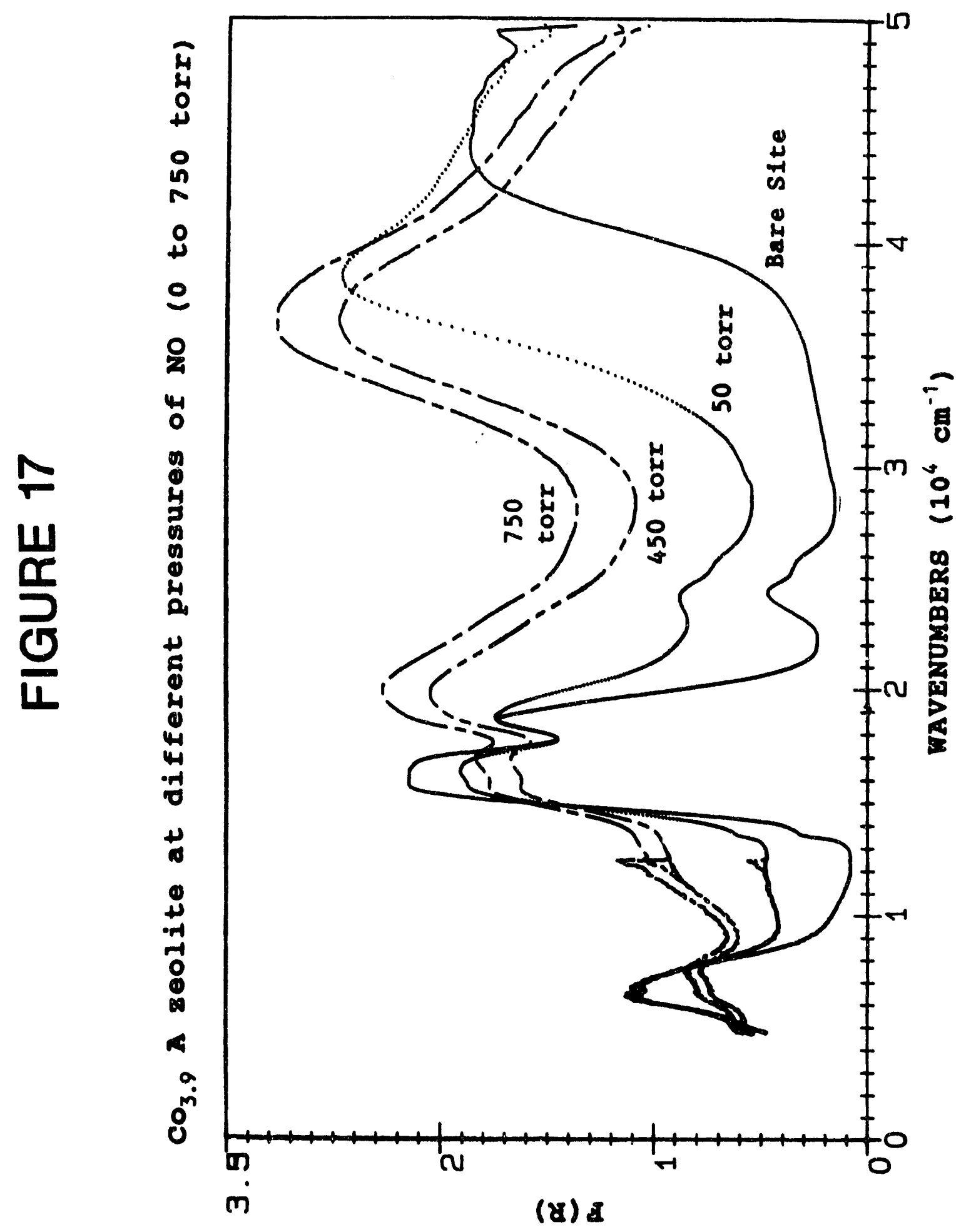




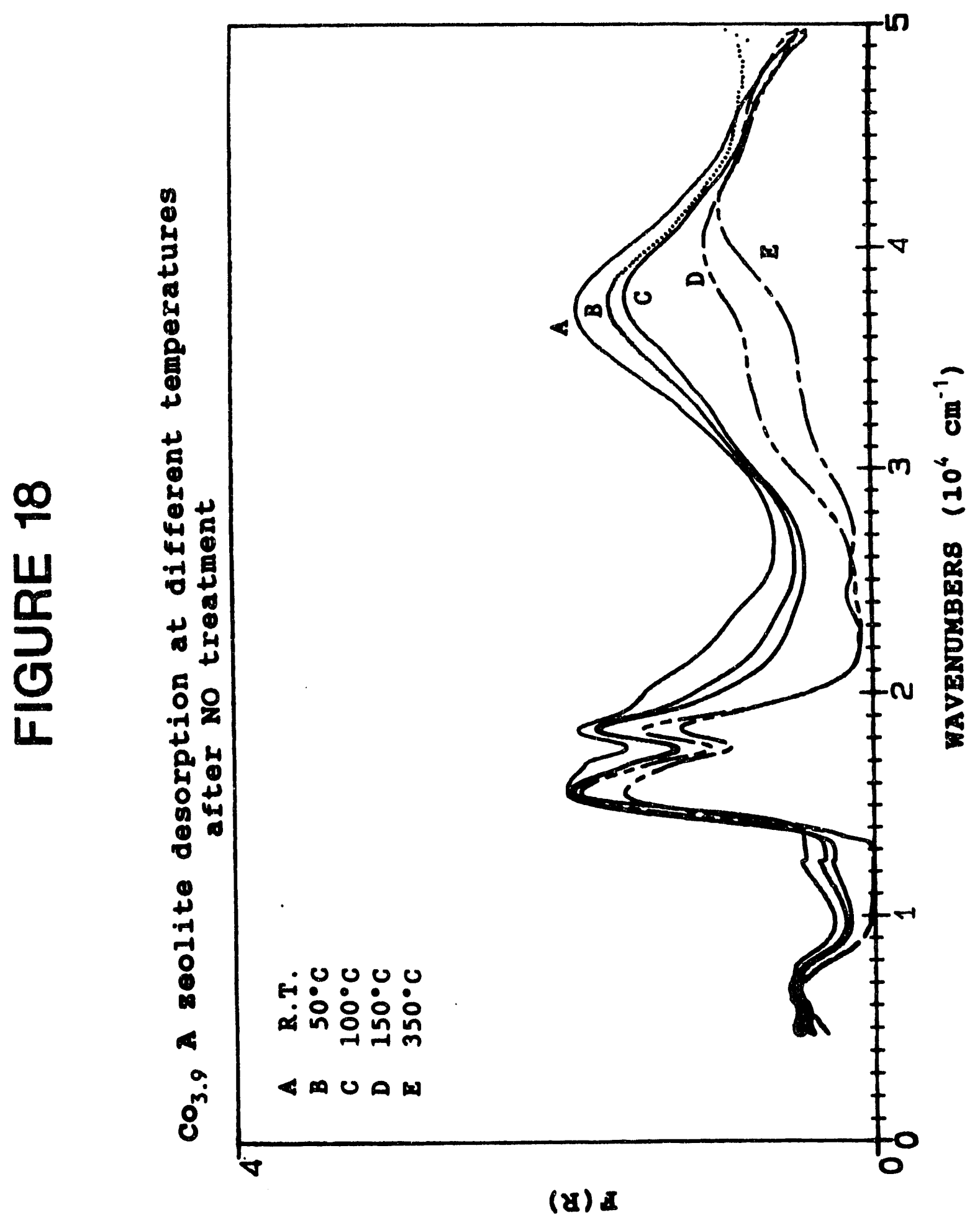




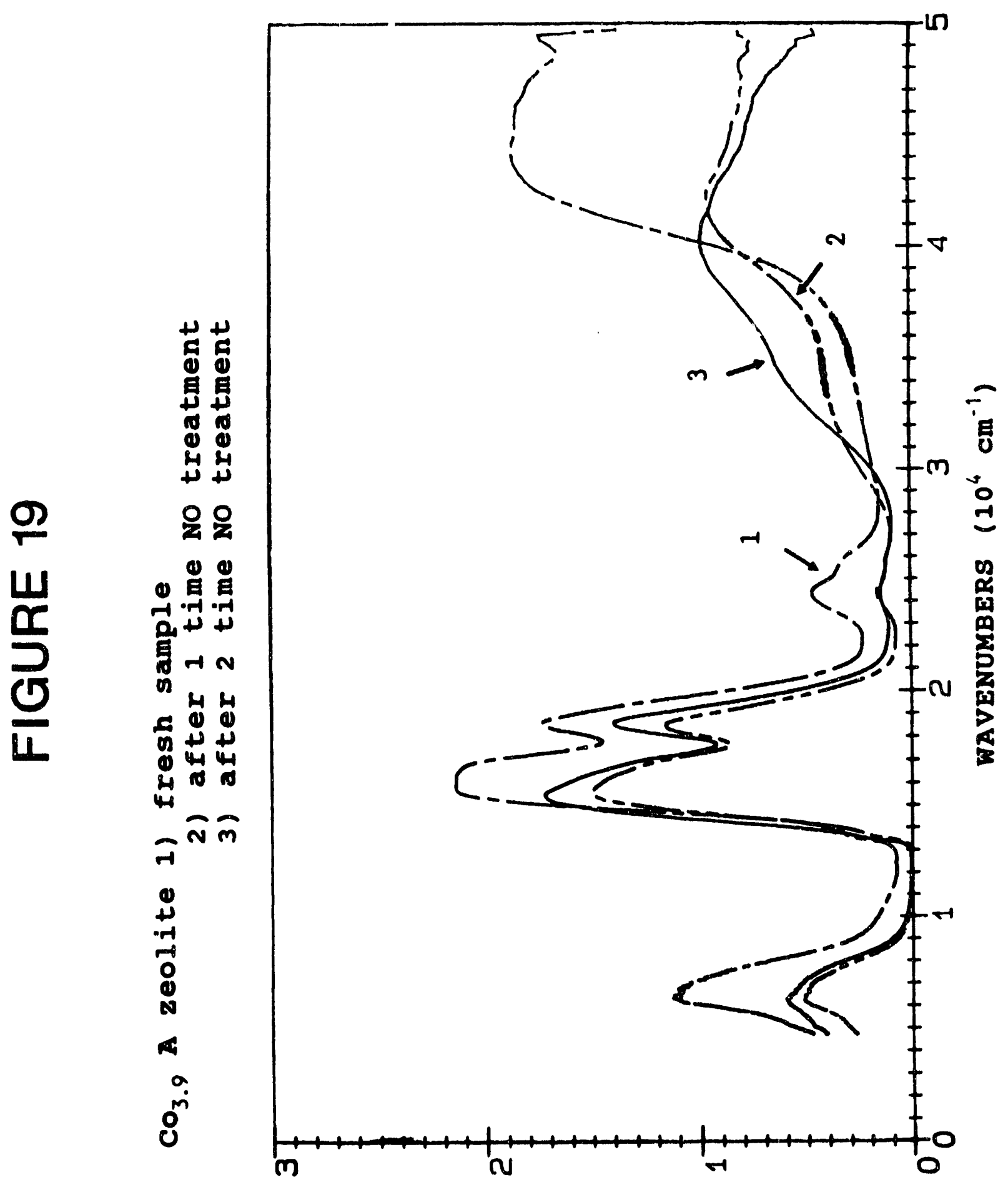

(d) 


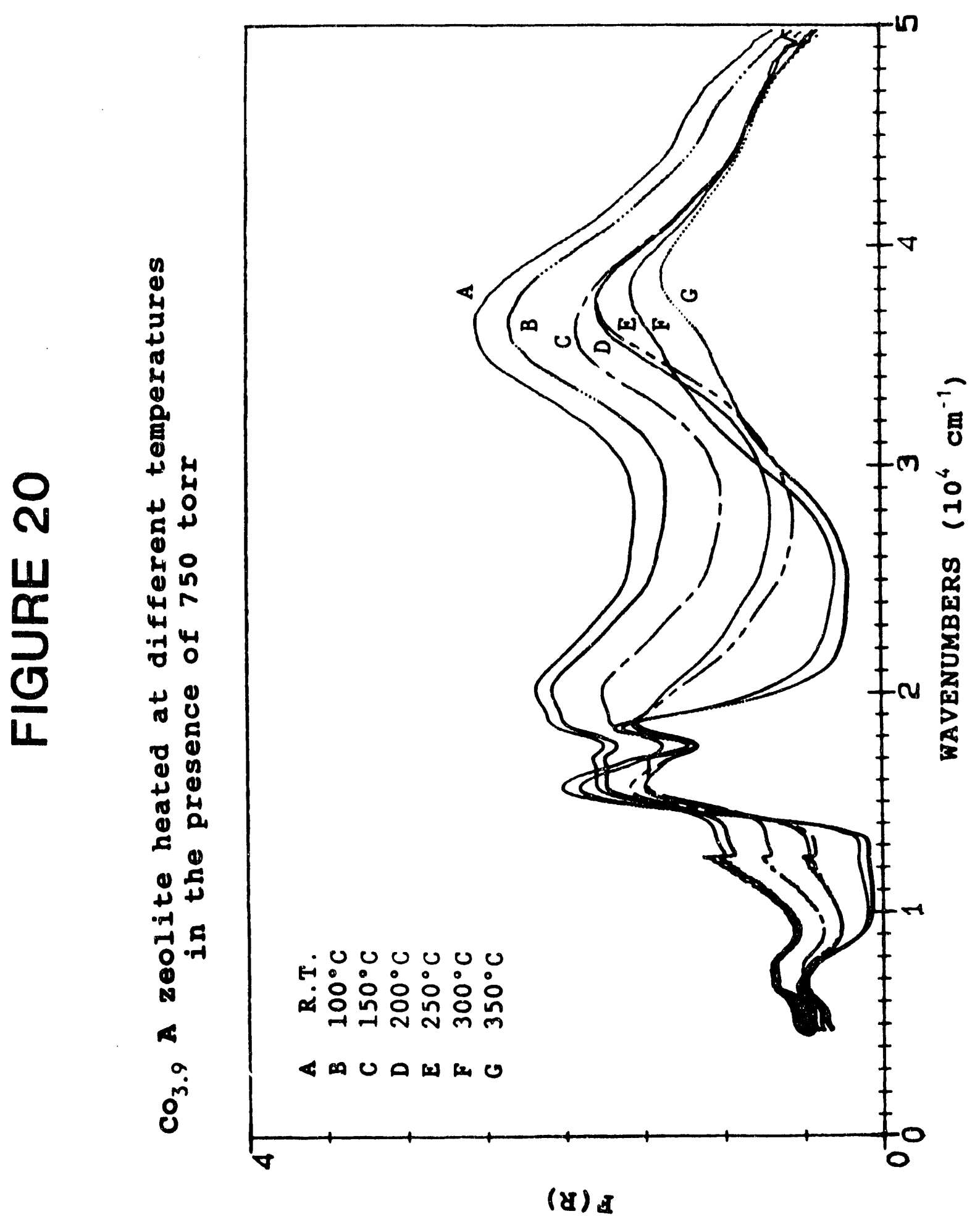


FIGURE 21

Gases components of NO(750 torr)on CoA at various temperatures.

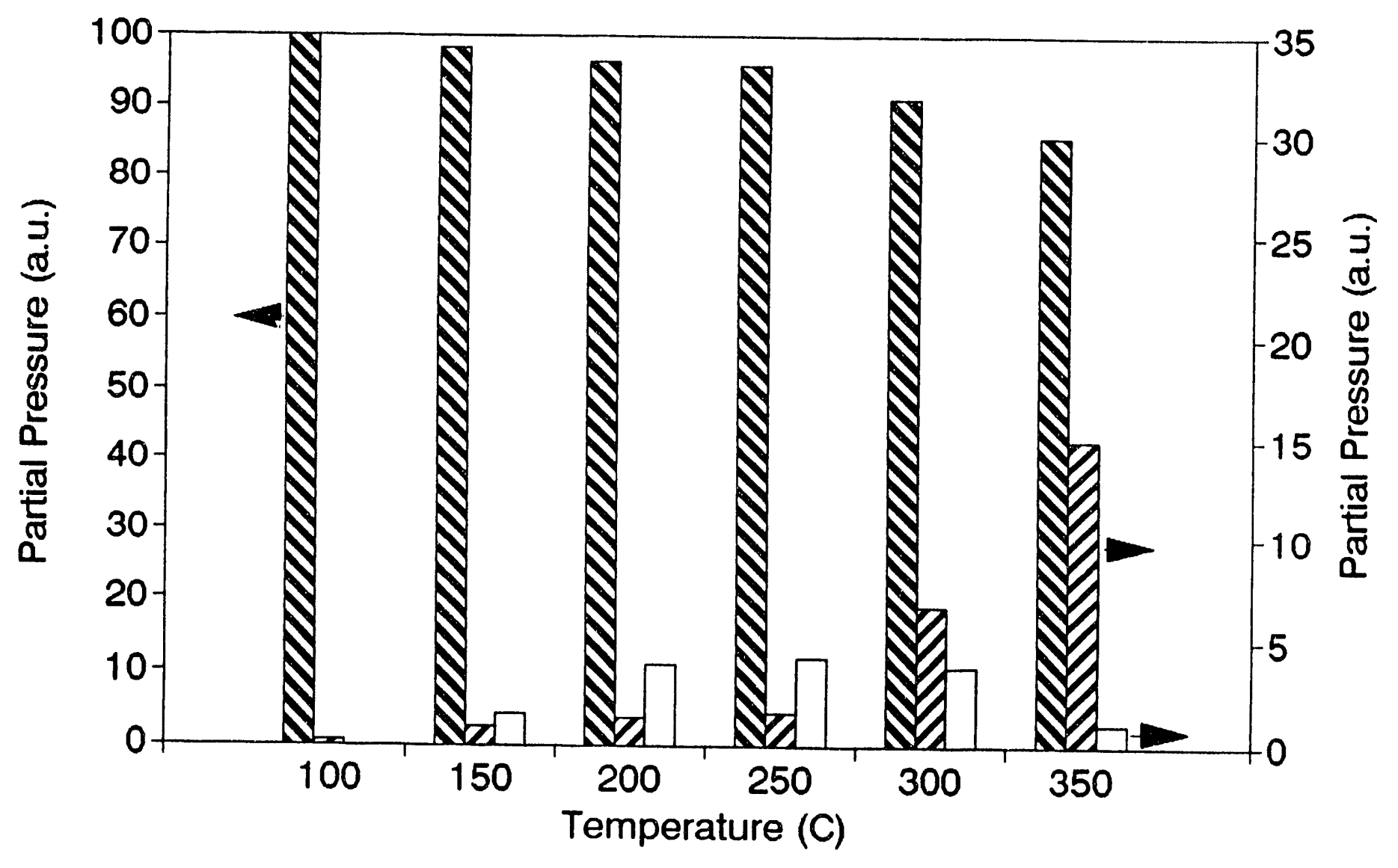

IIV No QZ N2 $\square$ N2O 


\section{FIGURE 22}

Gases components of $\mathrm{H} 2$ reduction of CoA at $350 \mathrm{C}$ after thermal evacuation.

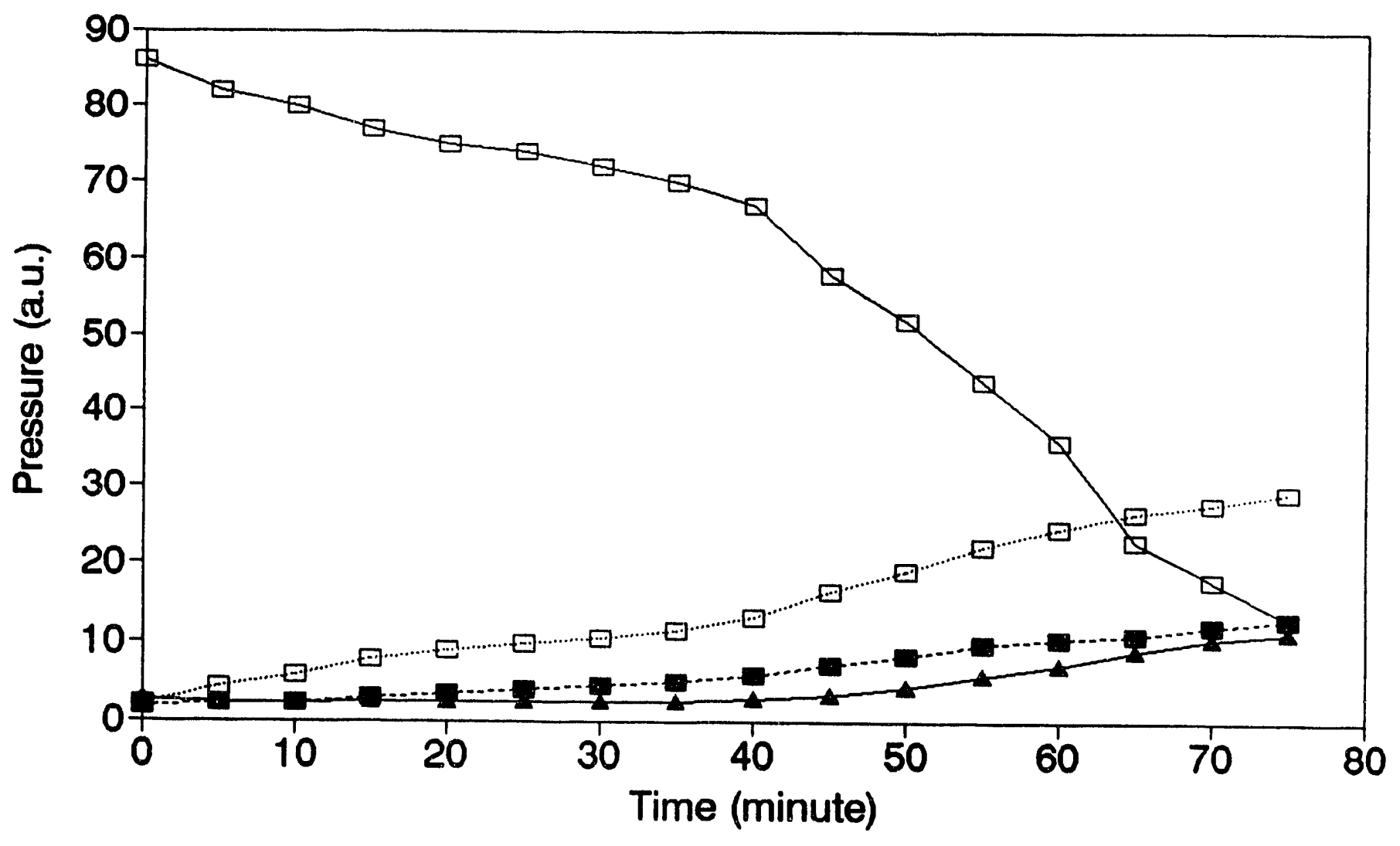

$$
\cdots \mathrm{H} 2 \mathrm{O} \cdots \mathrm{NO}-\mathrm{N} 2-\mathrm{N} 2
$$




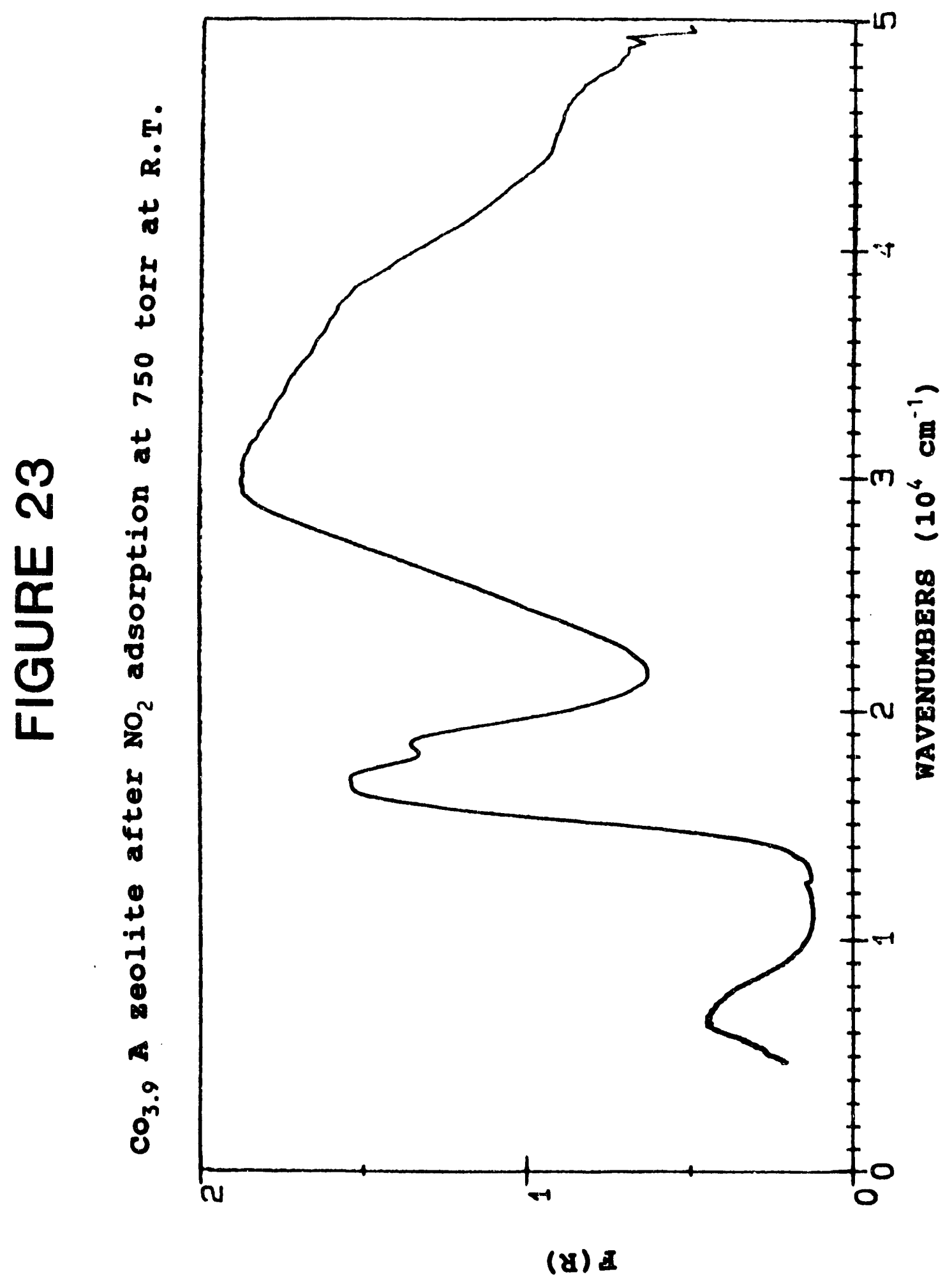




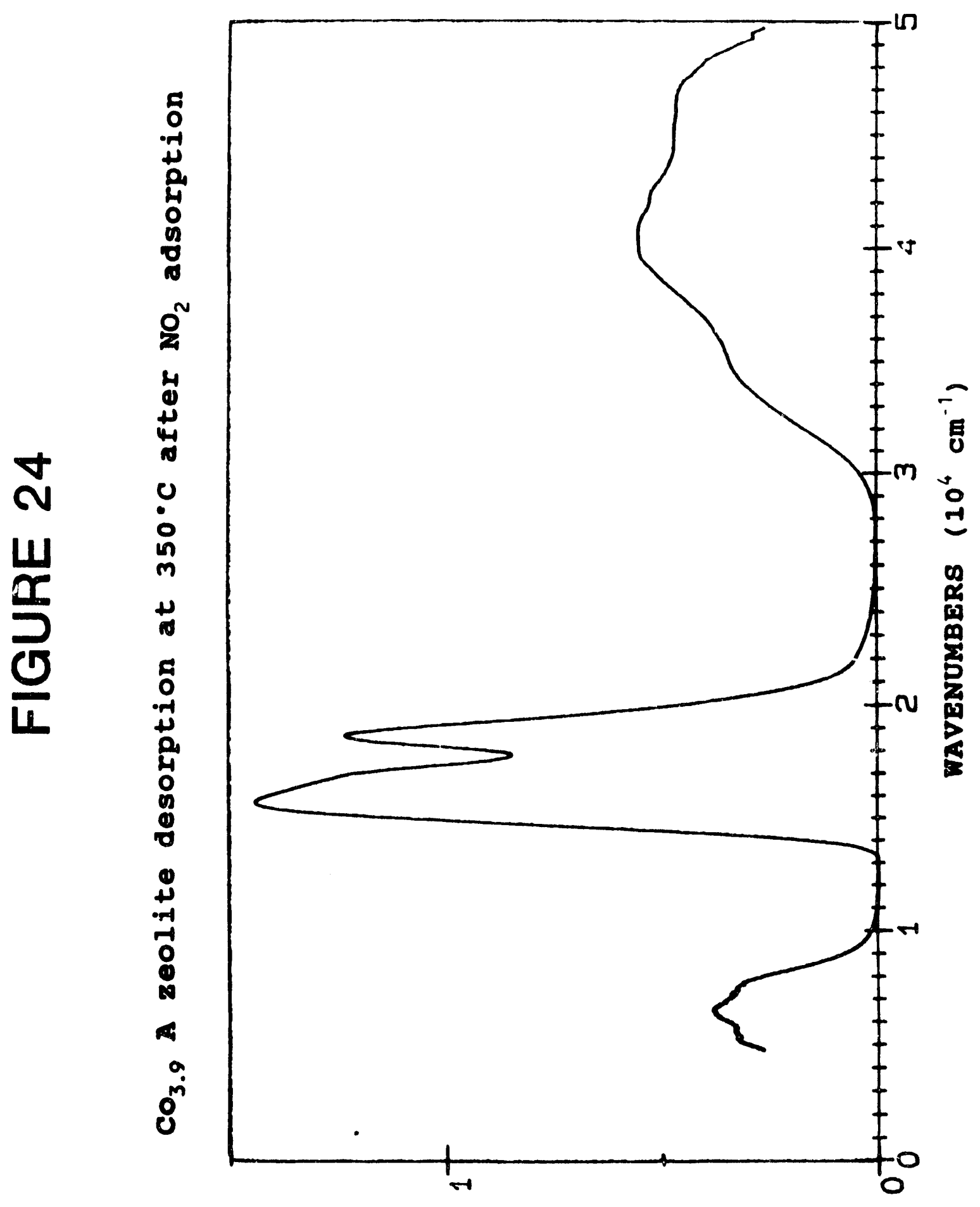

(d) 3 

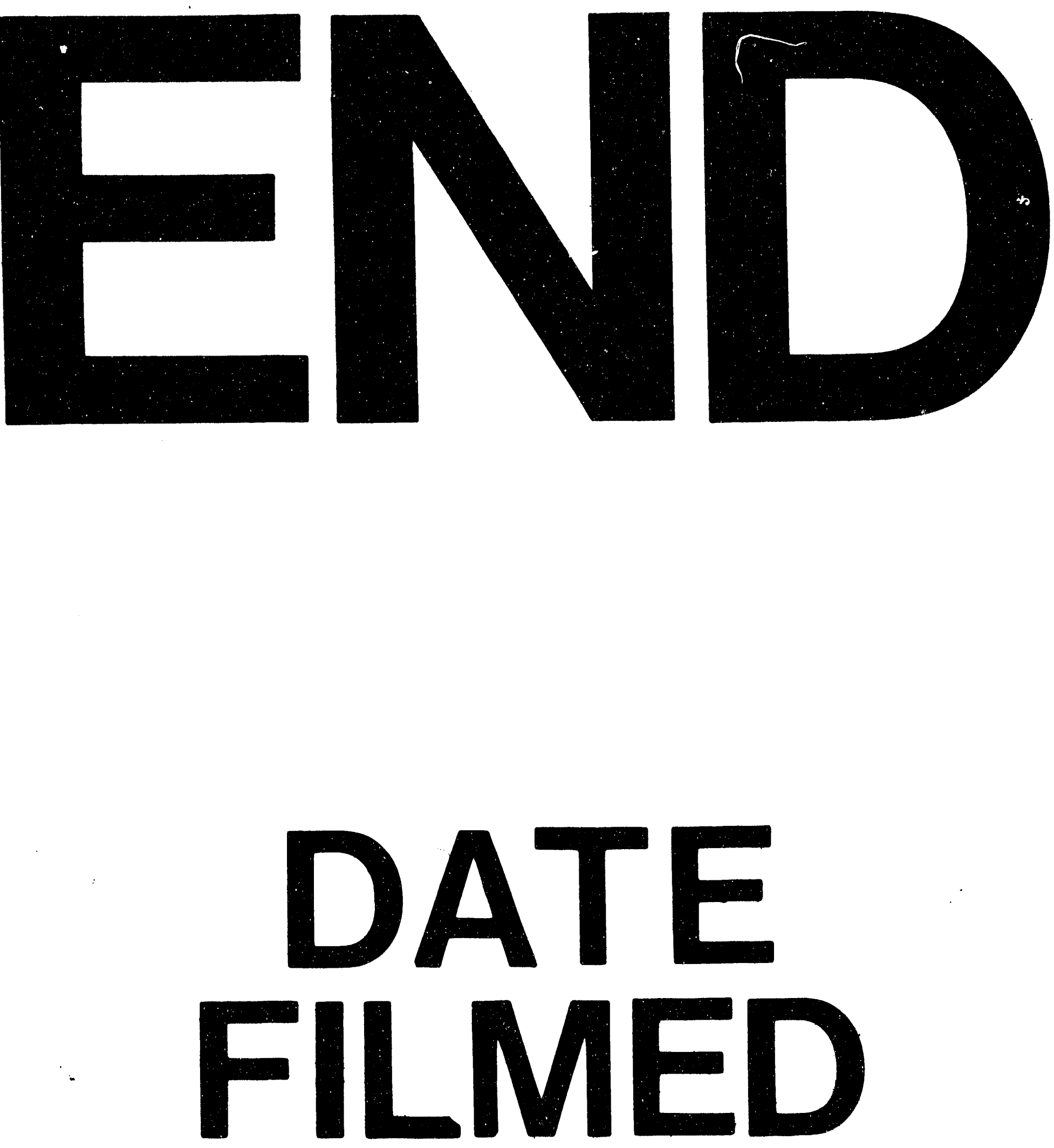

1

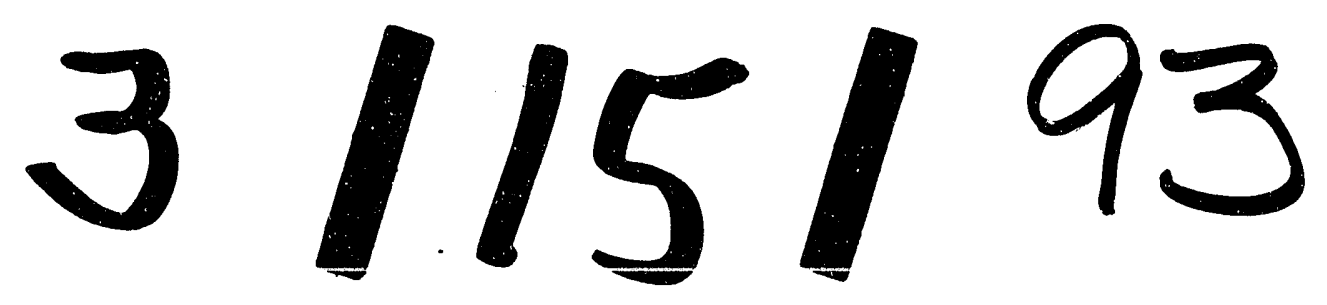


